\title{
Transgenerational Proteome Plasticity in Resilience of a Marine Copepod in Response to Environmentally Relevant Concentrations of Microplastics
}

\author{
Chen Zhang, ${ }^{\dagger}$ Chang-Bum Jeong, ${ }^{\S}$ Jae-Seong Lee, ${ }^{\S}$ Dazhi Wang, ${ }^{\dagger}$ and \\ Minghua Wang ${ }^{*},+$,
}

$\uparrow$ State Key Laboratory of Marine Environmental Science / College of the Environment \& Ecology, Xiamen University, Xiamen, 361102, China

$\S$ Department of Biological Science, College of Science, Sungkyunkwan University, Suwon 16419, South Korea

* Fujian Provincial Key Laboratory for Coastal Ecology and Environmental Studies, Xiamen University, Xiamen, 361102, China

* Corresponding author:

Dr. Minghua Wang

Email:mhwang45@xmu.edu.cn

Number of pages: 53

Number of figures: 7

Number of tables: 10 


\section{Text S1: Raman Spectroscopy Analysis}

For both the plain and fluorescently labeled polystyrene microbeads (Polyscience, Inc., Warrington, PA, USA), their polymer composition was analyzed using Raman spectroscopy (i-Raman Plus, B\&W Tek, Newark, USA). The excitation wavelength was $785 \mathrm{~nm}$ and a 20x objective was used. Raman spectra were collected with a resolution of $4.5 \mathrm{~cm}^{-1}$ in the wavenumber range from 150 to $3350 \mathrm{~cm}^{-1}$. The measuring parameters were set to a laser intensity of $100 \%(320 \mathrm{~mW})$ and an integration time of $2 \mathrm{~s}$. For each sample, the spectra were automatically measured three times and then averaged for further analysis. All spectra were analyzed using the BioRad KnowItAll Software and compared to the following spectral libraries: Horiba Raman Forensics, Horiba Raman Minerals, Bio-Rad Sadtler Raman Polymers and Monomers, and Bio-Rad Sadtler Polymers and Processing Chemicals. The BioRad KnowItAll Software program compares unknown spectra to known library spectra using a correlation algorithm. Search results are ranked with a Hit Quality Index value from 0 to $100 \%$. Only values of $70 \%$ or higher were accepted as a positive match. ${ }^{1}$ The Raman spectra indicated that the several peaks were considered as verification of polystyrene, namely, $622 \mathrm{~cm}^{-1}, 790 \mathrm{~cm}^{-1}, 1000 \mathrm{~cm}^{-1}, 1029 \mathrm{~cm}^{-1}, 1152 \mathrm{~cm}^{-1}, 1177 \mathrm{~cm}^{-1}$, and $1590 \mathrm{~cm}^{-1}$. Please note that the Raman spectra of both the plain and fluorescently labeled polystyrene microbeads were highly matched with polystyrene reference standard (Figure S1).

\section{Text S2: A Three-day Testing}

To measure whether the copepods could ingest microplastics, a three-day exposure was employed. In this ingestion test, we used fluorescently labeled (with an excitation of $441 \mathrm{~nm} /$ emission $486 \mathrm{~nm})$ polystyrene microbeads $(2.7 \%$ solids suspension; Polyscience, USA) with diameter of $6 \mu \mathrm{m}$ (similar in size to live food organisms) as our representative microplastics. Fluorescently labeled polystyrene beads were added in the seawater to achieve nominal concentrations of $0.023 \mathrm{mg} / \mathrm{L}(194$ particles/mL), and $0.23 \mathrm{mg} / \mathrm{L}$ (1937 particles $/ \mathrm{mL}$ ), respectively. The testing solutions were sonicated for $30 \mathrm{~min}$ before the experiment and daily renewed ( $90 \%$ of the working volume). 
Tigriopus japonicus adults (fifty copepods) were subjected to 0.023 and $0.23 \mathrm{mg} / \mathrm{L}$ microplastics treatments, respectively, in the polycarbonate bottles with $150 \mathrm{~mL}$ seawater solution (three replicates per concentration treatment). The microalgal culture was provided as prey for the copepods at a density of approximately $5 \times 10^{7}$ cells/L during exposure. The seawaters were daily collected for microbead concentration counting. Namely, at the beginning of day 1, after adding nominal microplatics $(0.023$ and $0.23 \mathrm{mg} / \mathrm{L})$ to the seawater, we immediately collected the testing solutions for both microplastics treatments. At the end of day 1 (but before the daily renewal of the solution), the seawater was also collected for both the above treatments. The same procedure was repeated for days 2 and 3. Each treatment was conducted in triplicate.

Also, another three-day test was performed to examine whether the polycarbonate bottle could absorb microbeads during exposure. The detailed protocol was the same as that described for the above ingestion testing, but no copepods were added in this case. The seawaters were daily collected for microbead concentration counting. That is to say, at end of days 1, 2 and 3, the testing solutions were collected.

\section{Text S3: Protein Extraction, TMT Labeling and Strong Cation Exchange (SCE)}

\section{Fractionation}

Proteins were extracted from the copepods under ultrasonication in lysis buffer $(8 \mathrm{M}$ urea, $2 \mathrm{mM}$ ethylenediaminetetraacetic acid, $10 \mathrm{mM}$ dithiothreitol (DTT), and 1\% Protease Inhibitor Cocktail) on ice. The precipitants were removed by centrifugation at $20000 \mathrm{~g}$ at $4^{\circ} \mathrm{C}$ for $10 \mathrm{~min}$. Afterwards, the proteins were precipitated with ice-cold $15 \%$ trichloroacetic acid for $2 \mathrm{~h}$ at $-20^{\circ} \mathrm{C}$. The supernatants were discarded by centrifugation at $20000 \mathrm{~g}$ at $4^{\circ} \mathrm{C}$ for $10 \mathrm{~min}$, and the protein deposits were rinsed three times with ice-cold acetone. The protein pellets were reformed by centrifuging at $20000 \mathrm{~g}$ at $4^{\circ} \mathrm{C}$ for $30 \mathrm{~min}$ each time. Remnant acetone was removed using vacuum centrifugation. The proteins were redissolved in $120 \mu \mathrm{L}$ buffer comprising $8 \mathrm{M}$ urea, and $100 \mathrm{mM}$ triethylammonium bicarbonate (TEAB), $\mathrm{pH}$ 8.0. The solutions were centrifuged at $20000 \mathrm{~g}$ for $30 \mathrm{~min}$ at $10^{\circ} \mathrm{C}$ and the supernatants were collected for 
TMT analysis. Protein contents were determined using the commercial 2-D Quant kit (GE Healthcare, USA).

For trypsin digestion, each protein sample $(100 \mu \mathrm{g})$ was reduced with $10 \mathrm{mM}$ DTT for $1 \mathrm{~h}$ at $37^{\circ} \mathrm{C}$, followed by an alkylation with $20 \mathrm{mM}$ iodoacetamide for $45 \mathrm{~min}$ in a dark room. After being diluted with $100 \mathrm{mM}$ TEAB to maintain a urea concentration less than $2 \mathrm{M}$, each protein solution was digested using trypsin (Promega, Madison, WI, USA) at the protein/trypsin mass ratio (50/1) overnight for the first digestion, followed by a second $4 \mathrm{~h}$ digestion with the protein/trypsin mass ratio (100/1). The reaction was maintained at $37^{\circ} \mathrm{C}$, and stopped by adding $200 \mu \mathrm{L}$ trifluoroacetic acid (0.1\%). Peptides were desalted using Strata X C18 SPE column (Phenomenex) and dried using vacuum centrifugation.

Peptides were resolved in $0.5 \mathrm{M}$ TEAB and subjected for TMT labeling following the manufacturer's instructions. In brief, one unit of TMT reagent (described as the amount of reagent required for labeling $100 \mu \mathrm{g}$ protein) was thawed and reconstituted in $24 \mu \mathrm{L}$ acetonitrile (ACN). Protein samples were labeled with the TMT tags in the following protocol: tags 126, 127 and 128 were designated to label the three replicates for the control in F1 ("F1-C") with tags 129, 130 and 131 for the microplastics treatment in F1 ("F1-M"). The F2 generation was labeled in the same way. Two runs of liquid chromatography-tandem mass spectrometry (LC-MS/MS) analysis were conducted for F1 and F2, respectively. The peptides were then incubated for $2 \mathrm{~h}$ at room temperature, and the labeling was terminated using 5\% hydroxylamine. Finally, all six samples were pooled and dried using vacuum centrifugation.

The sample was then prefractionated into fractions using high $\mathrm{pH}$ reverse-phase HPLC and an Agilent 300 Extend $\mathrm{C}_{18}$ column (5 $\mu \mathrm{m}$ particles, $4.6 \mathrm{~mm}$ ID, $250 \mathrm{~mm}$ length). In short, the peptides were first separated with a gradient of 2 to $60 \% \mathrm{ACN}$ in $10 \mathrm{mM}$ ammonium bicarbonate $(\mathrm{pH}, 10)$ over $80 \mathrm{~min}$ into 80 fractions. Then, the peptides were pooled into 20 fractions and subsequently vacuum-dried.

\section{Text S4: LC-MS/MS Analysis and Database Searching}

The peptide mixtures were redissolved in buffer A $(0.1 \%$ formic acid in $2 \% \mathrm{ACN})$ 
and directly loaded onto an EASY-nLC 1000 UPLC system. The peptides were fractionated using a 40 min gradient of $6-80 \%$ buffer B $(0.1 \%$ formic acid in $98 \%$ $\mathrm{ACN}$ ) at a constant flow rate of $0.30 \mu \mathrm{L} / \mathrm{min}$ on a reverse-phase analytical column (Acclaim PepMap RSLC, Thermo Scientific). Afterwards, the eluted peptides were analyzed using a tandem mass spectrometry (MS/MS) in Q Exactive ${ }^{\mathrm{TM}}$ Plus (Thermo).

The MS was processed with a data-dependent mode that automatically switched between MS and MS/MS scans. A survey full scan MS spectra in the Orbitrap (350$1800 \mathrm{~m} / \mathrm{z}, 70000$ resolution) was followed by $20 \mathrm{MS} / \mathrm{MS}$ scans using normalized collision energy setting as 30\%. Targeted precursor ions selected for MS/MS were dynamically excluded for $30 \mathrm{~s}$. Fragmented ions were detected in the Orbitrap at a 17500 resolution. Automatic gain control was set as $5 \times 10^{4}$ ions in order to prevent overfilling of the ion trap. Xcalibur software was used to acquire all the MS data.

Mascot search engine (v.2.3) was processed to search the resulting mass spectra against the NCBI_Tigriopus proteome (1746 sequences) and T. japonicus transcriptome (i.e., a total of 46369 sequences combined from a previous work ${ }^{2}$ and our published data $^{3}$ ) database. The cleavage enzyme was defined as trypsin, allowing up to two miscleavages. A mass tolerance of $10 \mathrm{ppm}$ was specified for precursor ions, and 0.02 Da for fragmented ions. Carbamidomethylation on cysteine, TMT-6plex (K) and TMT-6plex (N-term) were set as fixed modifications, while oxidation on methionine was defined as a variable modification. The estimated false discovery rate was specified at a maximum of $1 \%$ for both peptide and protein identification, and peptide ion score was set $>20$.

\section{Text S5: Biochemical Parameter Determination}

For the biochemical assays, the copepods were homogenized for $5 \min$ in $0.85 \%$ saline at $4{ }^{\circ} \mathrm{C}$, using a glass-glass Elvehjem-Potter homogenizer. The homogenate was centrifuged at $10000 \mathrm{~g}$ for $20 \mathrm{~min}$ at $4^{\circ} \mathrm{C}$, and the supernatant was provided for biochemical parameter determination using the commercial assay kits (Nanjing Jiancheng Bioengineering Institute, Nanjing, China). In other words, the activities of 
trypsin, cellulase (CL), and carboxylesterase (CarE) were measured following the manufacturer's instructions. Protein content determination was performed according to the Bradford Coomassie brilliant blue method with bovine serum albumin as a standard.

\section{REFERENCES}

1. Lusher, A. L.; Welden, N. A.; Sobral, P.; Cole, M., Sampling, isolating and identifying microplastics ingested by fish and invertebrates. Analytical Methods 2017, 9, 1346-1360.

2. Kim, H.-S.; Lee, B.-Y.; Won, E.-J.; Han, J.; Hwang, D.-S.; Park, H. G.; Lee, J.-S., Identification of xenobiotic biodegradation and metabolism-related genes in the copepod Tigriopus japonicus whole transcriptome analysis. Marine Genomics 2015, 24, Part 3, 207-208.

3. Wang, M.; Jeong, C.-B.; Li, Y.; Lee, J.-S., Different transcriptomic responses of two marine copepods, Tigriopus japonicus and Pseudodiaptomus annandalei, to a low dose of mercury chloride $\left(\mathrm{HgCl}_{2}\right)$. Aquatic Toxicology 2017, 187, 124-131.

\section{Figure captions}


Figure S1. Characterization of both polystyrene microparticles: size (a), and Raman spectra of tested polystyrene microparticles (b). Please note that the Raman spectra of both the plain (red curve) and fluorescently labeled (blue curve) polystyrene microbeads were highly matched with polystyrene reference standard (green curve).

Figure S2. Effects of microplastics on (a) sex ratio (F/M) and (b) number of clutches in Tigriopus japonicus under two-generation exposure to the control, 023 and 0.23 $\mathrm{mg} / \mathrm{L}$ microplastics treatments. Data are described as mean \pm standard deviation $(\mathrm{n}=$ 3). Different letters indicate a significant difference among different treatments at $p<$ 0.05 .

Figure S3. Effects of microplastics on (a) nauplius phase and (b) development time in Tigriopus japonicus under two-generation exposure to the control, 023 and $0.23 \mathrm{mg} / \mathrm{L}$ microplastics treatments. Data are described as mean \pm standard deviation $(n=3)$. Different letters indicate a significant difference among different treatments at $p<$ 0.05 .

Figure S4. Venn diagram indicating the overlaps of identified proteins (a) and differentially expressed proteins (b) of the two proteome sets in Tigriopus japonicus.

Figure S5. The reproducibility was performed for three biological replicates per treatment. Box plot indicated high reproducibility because standard deviation coefficient was calculated at less than 0.1 for three replicates per sample. F1-C represented the control in F1, and F1-M for the microplastics $(0.23 \mathrm{mg} / \mathrm{L})$ treatment in $\mathrm{F} 1$; F2-C represented the control in F2, and F2-M for the microplastics $(0.23 \mathrm{mg} / \mathrm{L})$ treatment in F2.

Figure S6. Functional classifications were performed for differentially expressed proteins in the copepod Tigriopus japonicus of the F1 (a) and F2 (b) generations. 
Figure S7. Comparison of the enzyme activity and protein expression in Tigriopus japonicus in the recovery generation (F2). CL represented cellulase, and CarE for carboxylesterase. Data are described as mean \pm standard deviation $(n=3)$. 


\section{Figure S1}

a

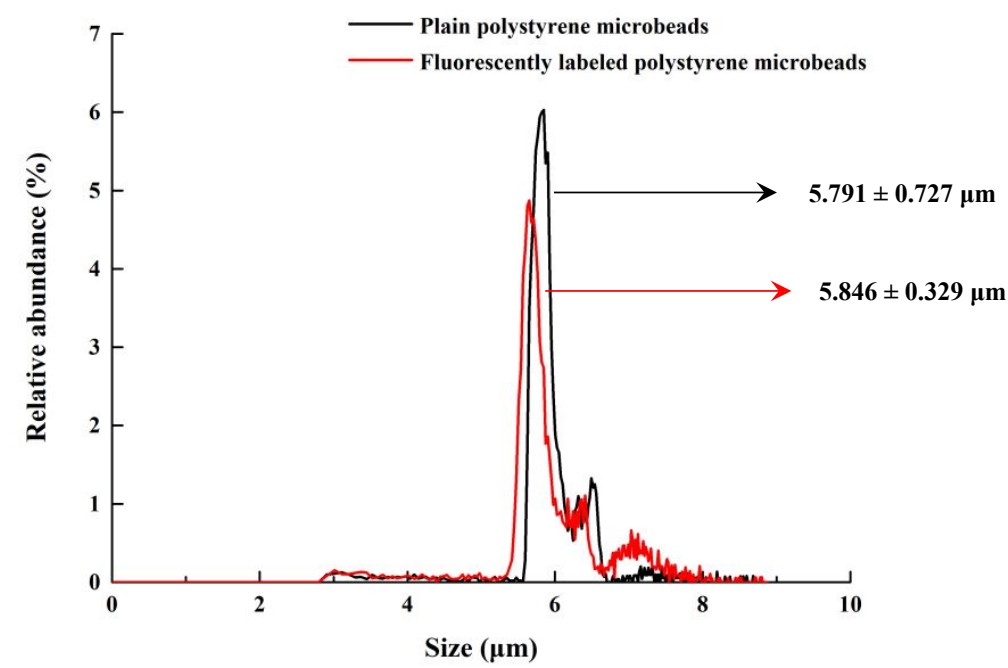

b

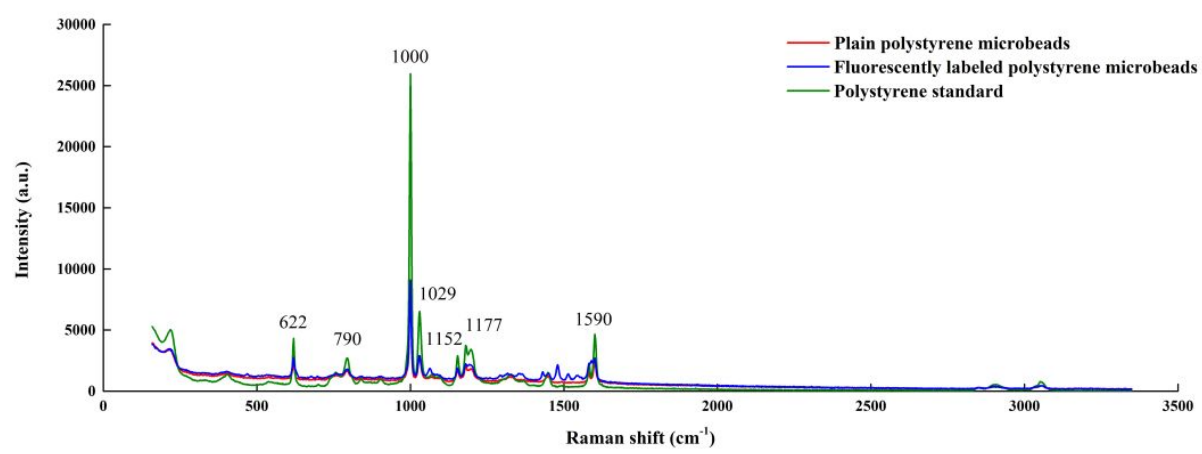


Figure S2

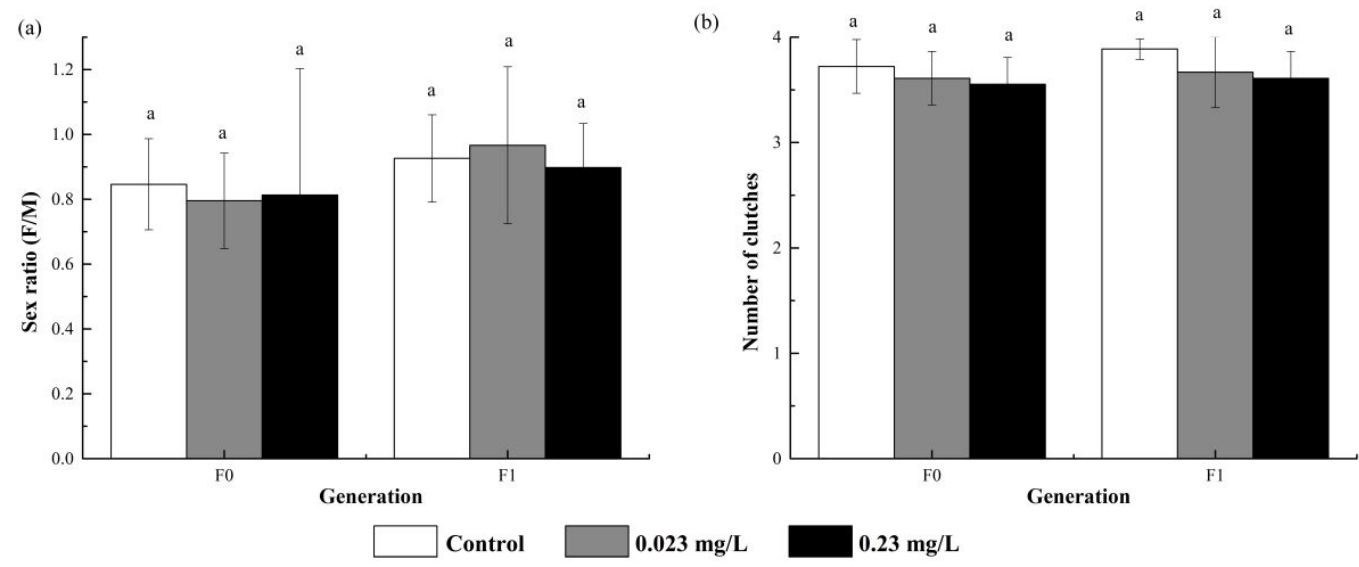


Figure S3

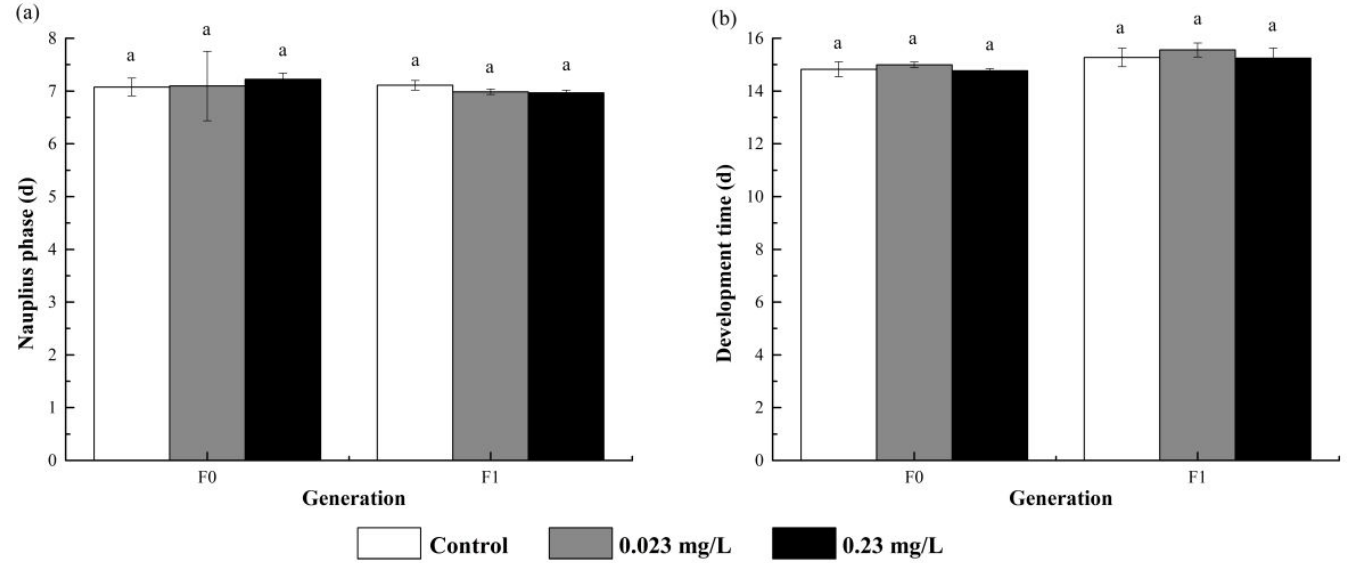


Figure S4

a

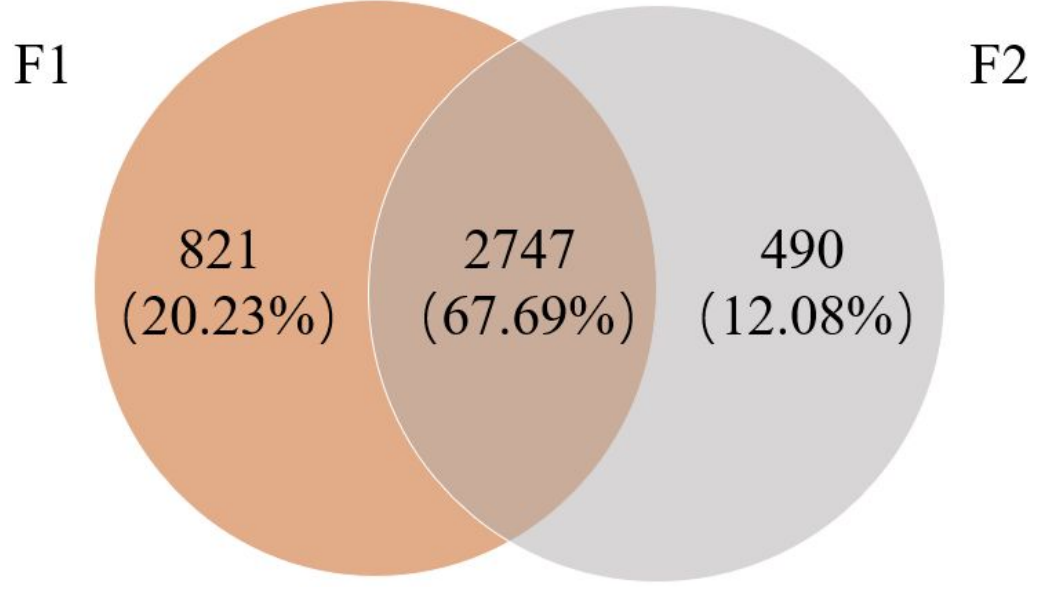

b

F1

F2
23
12
362
$(5.79 \%)$
$(3.02 \%) \quad(91.19 \%)$ 
Figure S5

a

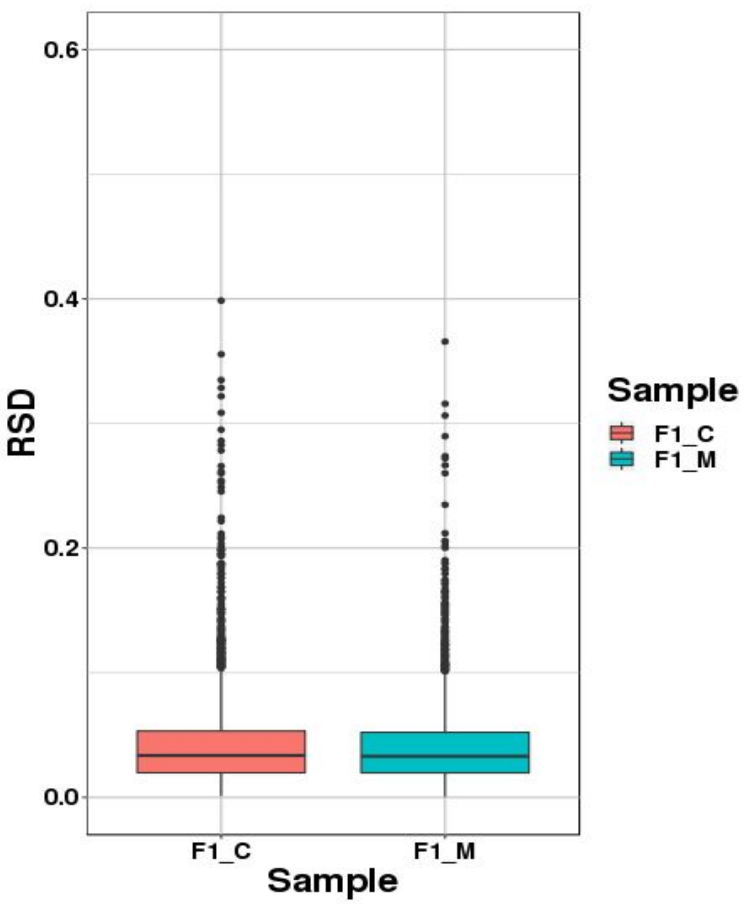

b

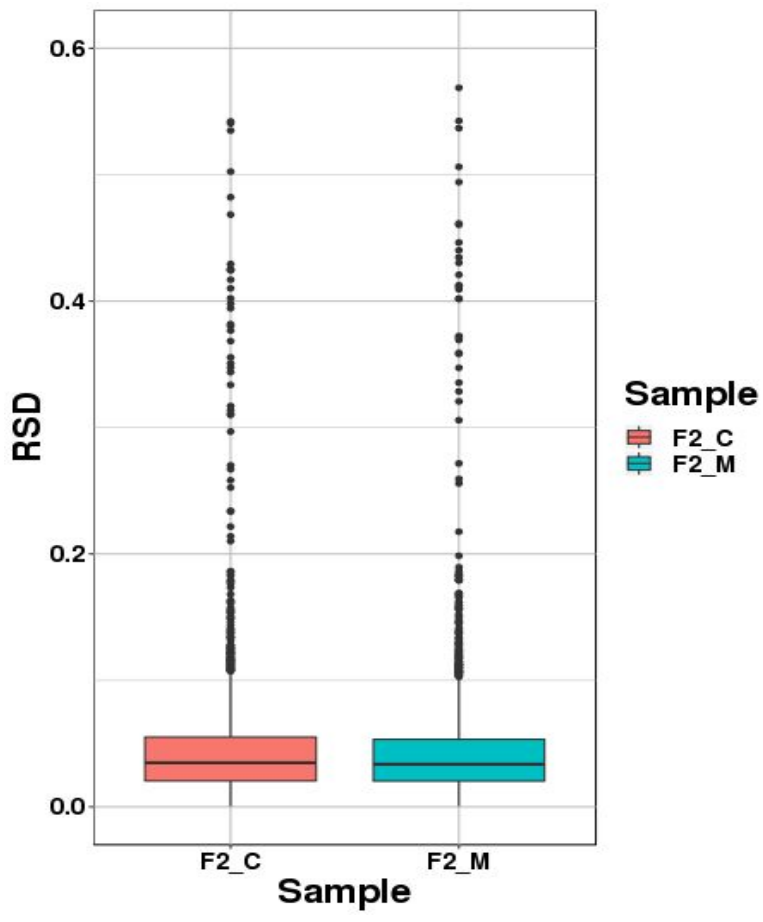




\section{Figure S6}
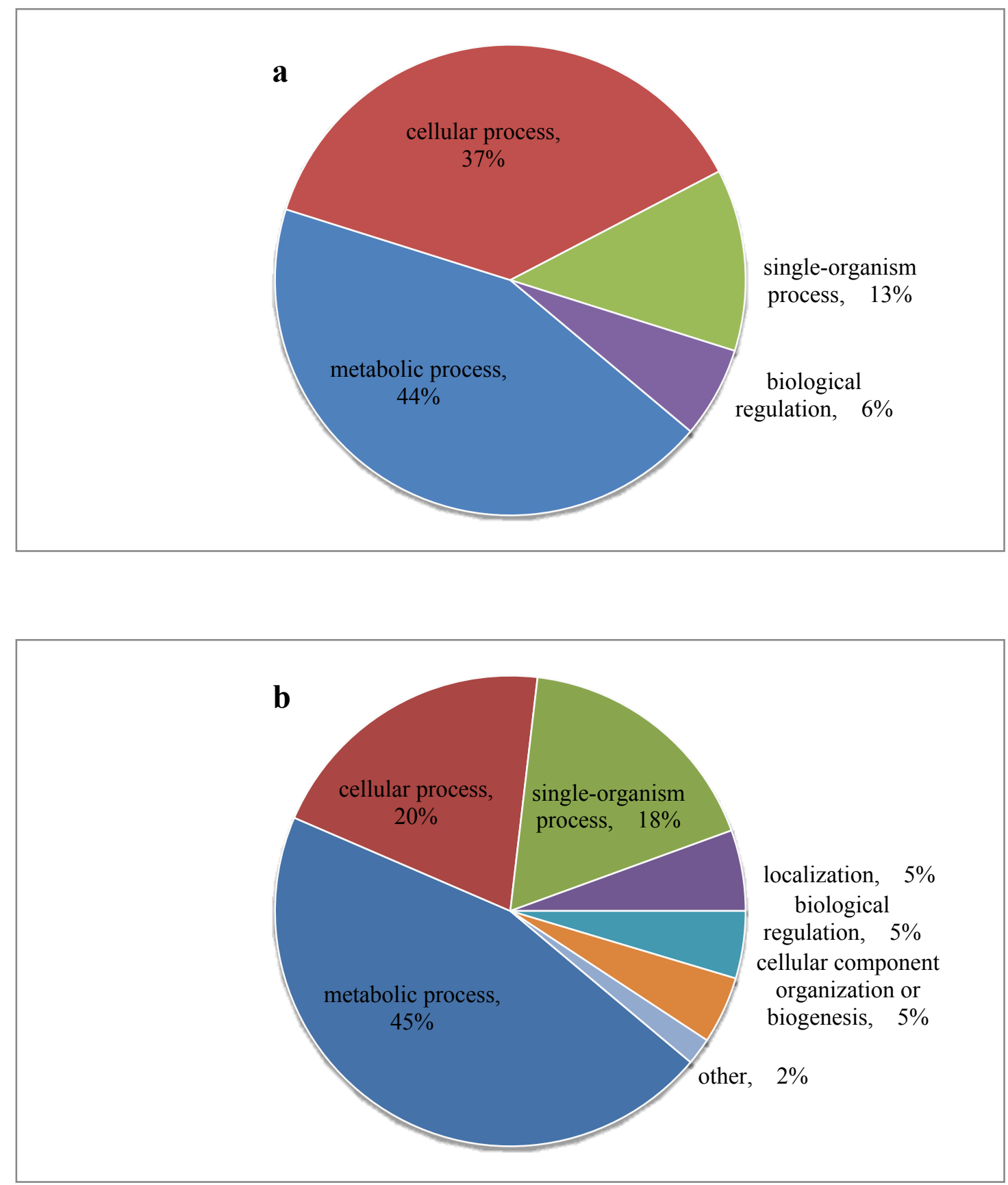
Figure S7

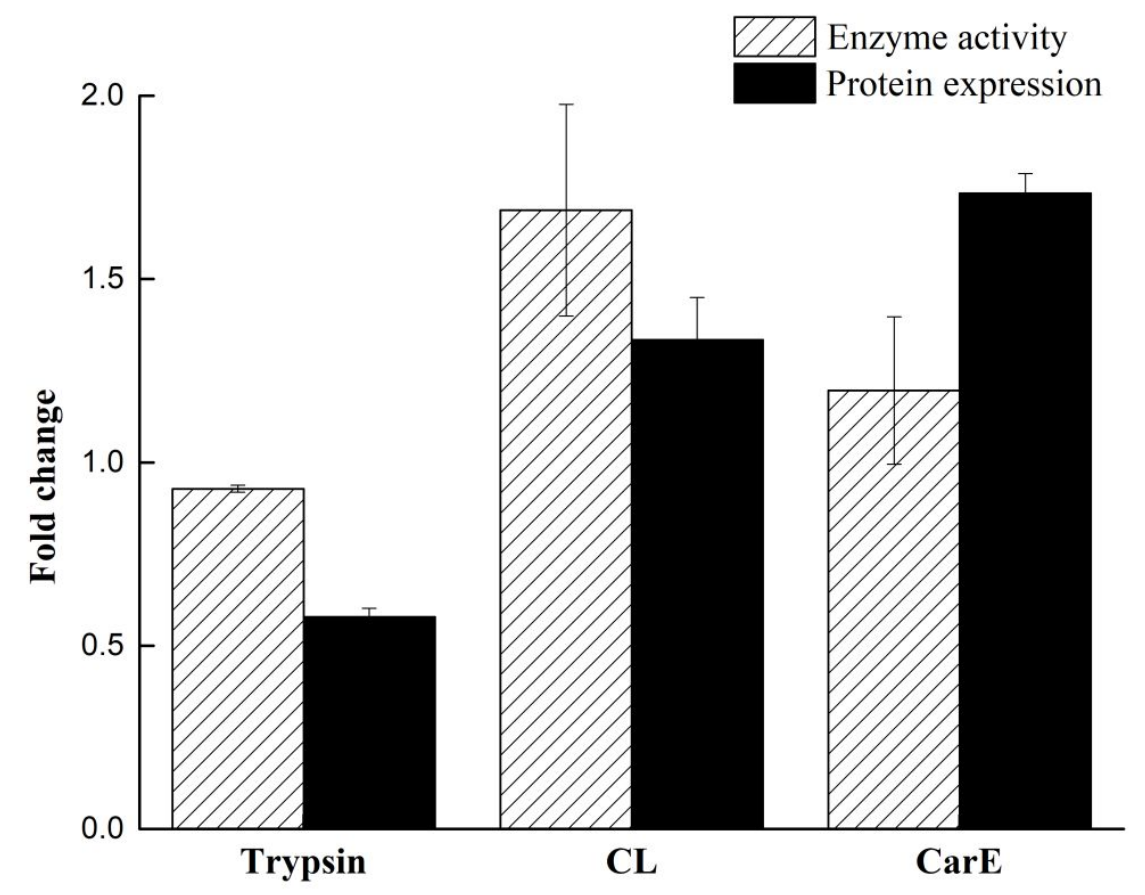


Table S1. Polystyrene microbeads used in this study.

\begin{tabular}{cccc}
\hline Test & Solids & Microplastics & Diameter $(\boldsymbol{\mu m})$ \\
\hline Ingestion test & $2.7 \%$ & $\begin{array}{c}\text { Fluoresbrite } \AA \text { YG } \\
\text { Microspheres }\end{array}$ & $5.73 \pm 0.43$ \\
$\begin{array}{c}\text { Multigenerational } \\
\text { exposure test }\end{array}$ & $2.5 \%$ & Polybead $\AA$ Microspheres & $5.93 \pm 0.29$ \\
\hline
\end{tabular}


Table S2. Microbead levels in the seawater solutions for both microplastics treatments during a three-day exposure.

\section{Microbead levels (mg/L)}

\begin{tabular}{ccccccc} 
Treatment (mg/L) & Sample 1 & Sample 2 & Sample 3 & Sample 4 & Sample 5 & Sample 6 \\
\cline { 2 - 7 } 0.023 & $0.024 \pm 0.001$ & $0.014 \pm 0.005$ & $0.021 \pm 0.005$ & $0.013 \pm 0.003$ & $0.021 \pm 0.002$ & $0.013 \pm 0.002$ \\
0.23 & $0.24 \pm 0.02$ & $0.13 \pm 0.09$ & $0.23 \pm 0.01$ & $0.16 \pm 0.02$ & $0.24 \pm 0.02$ & $0.14 \pm 0.02$ \\
\hline
\end{tabular}

Sample 1 represents the seawaters collected at the beginning of Day 1, Sample 2 for at the end of Day 1, Sample 3 for at the beginning of Day 2, Sample 4 for at the end of Day 2, Sample 5 for at the beginning of Day 3, and Sample 6 for at the end of Day 3. Data are described as mean \pm standard deviation $(\mathrm{n}=3)$. 
Table S3. Microplastics adsorption test was conducted for polycarbonate bottles during a three-day exposure.

\begin{tabular}{cccc}
\hline & \multicolumn{3}{c}{ Microplastics levels $(\mathrm{mg} / \mathrm{L})$} \\
\cline { 2 - 4 } Treatment $(\mathbf{m g} / \mathbf{L})$ & Sample 1 & Sample 2 & Sample 3 \\
\cline { 2 - 4 } 0.023 & $0.024 \pm 0.001$ & $0.023 \pm 0.001$ & $0.023 \pm 0.001$ \\
0.23 & $0.23 \pm 0.01$ & $0.22 \pm 0.02$ & $0.24 \pm 0.02$ \\
\hline
\end{tabular}

Sample 1 represents the seawaters collected at the end of Day 1, Sample 2 for at the end of Day 2, and Sample 3 for at the end of Day 3. Data are described as mean \pm standard deviation $(n=3)$. 
Table S4. A summary for quantitative data in protein identity for the two Tigriopus japonicus proteome sets via mass spectrometry analysis.

\begin{tabular}{lllllll}
\hline $\begin{array}{l}\text { Group } \\
\text { name }\end{array}$ & $\begin{array}{l}\text { Total } \\
\text { spectra }\end{array}$ & Spectra & Peptide & $\begin{array}{l}\text { Unique } \\
\text { peptide }\end{array}$ & Protein & FDR \\
\hline F1 & 239629 & 29566 & 14097 & 13803 & 3568 & 0.01 \\
F2 & 240631 & 25628 & 12505 & 12262 & 3237 & 0.01 \\
\hline
\end{tabular}


Table S5. The up-regulated proteins for Tigriopus japonicus after two-generation exposure to microplastics $(0.23 \mathrm{mg} / \mathrm{L})$ treatment versus ambient condition (i.e., F1-M versus F1-C).

\begin{tabular}{|c|c|c|c|c|c|c|c|c|c|}
\hline Protein accession & Protein description & Gene name & F1 ratio & P value & MW [kDa] & pI & AASC $[\%]$ & MP & Score \\
\hline c12148_g1_orf1 & $\begin{array}{l}\text { Citrate lyase subunit beta-like protein, mitochondrial } \\
\text { precursor }\end{array}$ & CLYBL & 1.487 & 4.42E-03 & 39.572 & 6.74 & 6.3 & 2 & 13.666 \\
\hline c1391_g1_orf1 & ribosomal protein S19 & RPS19A & 1.37 & $1.66 \mathrm{E}-02$ & 17.881 & 9.59 & 5.7 & 1 & 6.9075 \\
\hline c14352_g1 & & Unknown & 1.343 & $9.61 \mathrm{E}-04$ & 57.301 & 5.39 & 5.5 & 3 & 24.514 \\
\hline c16070_g1_orf1 & PREDICTED: ectoine hydroxylase-like & Unknown & 1.302 & $2.51 \mathrm{E}-02$ & 21.223 & 6.1 & 5.3 & 1 & 9.8863 \\
\hline c16486_g1 & & Unknown & 1.508 & $1.82 \mathrm{E}-02$ & 39.396 & 5.58 & 6.3 & 3 & 37.091 \\
\hline c17030_g1_orf1 & PREDICTED: usherin-like & Unknown & 1.313 & $3.33 \mathrm{E}-02$ & 18.762 & 7.93 & 6.4 & 1 & 14.025 \\
\hline c19080_g1 & & Unknown & 1.459 & $2.31 \mathrm{E}-02$ & 59.979 & 5.75 & 3.3 & 2 & 14.667 \\
\hline c20556_g1_orf1 & PREDICTED: macrophage mannose receptor 1-like & Unknown & 1.314 & $6.80 \mathrm{E}-03$ & 31.421 & 8.63 & 14.9 & 3 & 40.633 \\
\hline c21384_g1_orf1 & PREDICTED: 60S ribosomal protein L3 & Rpl3 & 1.343 & $2.15 \mathrm{E}-02$ & 44.412 & 10.12 & 4.1 & 1 & 8.1834 \\
\hline c21677_g1 & & Unknown & 1.508 & 7.92E-03 & 50.684 & 4 & 1.8 & 1 & 6.4399 \\
\hline c22608_g1_orf1 & hypothetical protein CAPTEDRAFT_114900 & Mmaa & 1.829 & $3.03 \mathrm{E}-04$ & 43.942 & 9.4 & 2.6 & 1 & 6.0894 \\
\hline c234_g1_orf1 & Proteasome activator complex subunit 4 & PSME4 & 1.923 & $3.84 \mathrm{E}-02$ & 227.52 & 6.21 & 1.4 & 3 & 19.456 \\
\hline c23513_g1 & & Unknown & 1.71 & $1.46 \mathrm{E}-02$ & 71.205 & 8.84 & 1.3 & 1 & 6.1023 \\
\hline c25418_g1 & & Unknown & 1.394 & $1.04 \mathrm{E}-02$ & 32.182 & 5.08 & 3.3 & 1 & 9.2701 \\
\hline c33417_g1 & & Unknown & 1.507 & $2.02 \mathrm{E}-02$ & 43.209 & 8.47 & 6.3 & 2 & 12.372 \\
\hline c40929_g1 & & Unknown & 1.475 & $6.80 \mathrm{E}-03$ & 11.508 & 4.24 & 8.7 & 1 & 8.2998 \\
\hline c42840_g1_orf1 & RNA-binding protein Hfq & hfq & 1.526 & $8.43 \mathrm{E}-05$ & 8.9573 & 9.9 & 16.5 & 1 & 7.4061 \\
\hline c44055_g1_orf1 & PREDICTED: 40S ribosomal protein S28-like & RPS28 & 1.466 & $1.92 \mathrm{E}-03$ & 7.6137 & 10.37 & 16.7 & 1 & 7.002 \\
\hline c46958_g1_orf1 & hypothetical protein & Unknown & 1.385 & $1.28 \mathrm{E}-02$ & 63.783 & 8.49 & 9.6 & 5 & 42.673 \\
\hline
\end{tabular}


Table S5. To be continued.

\begin{tabular}{|c|c|c|c|c|c|c|c|c|c|}
\hline Protein accession & Protein description & Gene name & F1 ratio & P value & MW [kDa] & pI & AASC $[\%]$ & MP & Score \\
\hline c54324_g1 & & Unknown & 1.579 & $3.16 \mathrm{E}-02$ & 5.5713 & 8.14 & 24.5 & 1 & 9.4849 \\
\hline c57692_g1_orf1 & PREDICTED: elongation factor Tu-like & tuf & 1.486 & $1.50 \mathrm{E}-03$ & 7.6295 & 8.3 & 17.1 & 1 & 22.125 \\
\hline c5880_g1 & & Unknown & 7.131 & $1.42 \mathrm{E}-03$ & 12.659 & 5.11 & 17.5 & 2 & 24.064 \\
\hline c60386_g1 & & Unknown & 1.634 & 2.64E-02 & 6.5698 & 9.7 & 13.8 & 1 & 6.9252 \\
\hline c62644_g1_orf1 & 40S ribosomal protein $\mathrm{S} 14$, putative & rpsK & 1.811 & $4.01 \mathrm{E}-04$ & 7.4825 & 9.59 & 17.1 & 1 & 8.1691 \\
\hline c63254_g1 & & Unknown & 1.864 & $1.17 \mathrm{E}-02$ & 29.6 & 8.26 & 3.5 & 1 & 7.0811 \\
\hline c9831_g1 & & Unknown & 1.719 & $4.43 \mathrm{E}-02$ & 56.83 & 4.93 & 1.7 & 1 & 6.7206 \\
\hline c9875_g1 & & Unknown & 1.58 & $1.45 \mathrm{E}-02$ & 53.388 & 4.61 & 13.2 & 6 & 42.205 \\
\hline c5157_g1 & & Unknown & 1.42 & $2.40 \mathrm{E}-02$ & 78.712 & 5.32 & 7.3 & 5 & 40.8 \\
\hline
\end{tabular}

F1 ratio: the average ratio for three replicates of F1-M versus F1-C. MW: molecular weight. pI: isoelectric point. AASC: amino acid sequence coverage. MP: matched unique peptide. 
Table S6. The down-regulated proteins for Tigriopus japonicus after two-generation exposure to microplastics $(0.23 \mathrm{mg} / \mathrm{L})$ treatment versus ambient condition (i.e., F1-M versus F1-C).

\begin{tabular}{|c|c|c|c|c|c|c|c|c|c|}
\hline Protein accession & Protein description & Gene name & F1 ratio & P value & MW [kDa] & pI & AASC [\%] & MP & Score \\
\hline c19848_g1_orf1 & sphingomyelin phosphodiesterase, putative & SMPD1 & 0.754 & $3.02 \mathrm{E}-03$ & 54.47 & 4.4 & 1.9 & 1 & 7.473 \\
\hline c2017_g2_orf1 & PREDICTED: 40S ribosomal protein S12-like & rps12 & 0.767 & $2.06 \mathrm{E}-02$ & 17.094 & 5.85 & 16.2 & 2 & 44.137 \\
\hline c2222_g1_orf1 & hypothetical protein TcasGA2_TC010336 c & Zc3h18 & 0.751 & $3.18 \mathrm{E}-02$ & 78.641 & 9.01 & 1.7 & 1 & 7.8199 \\
\hline c24185_g1_orf1 & microsomal GST3, partial & Mgst3 & 0.764 & $7.16 \mathrm{E}-04$ & 16.835 & 9.65 & 17.2 & 2 & 32.671 \\
\hline c24607_g1_orf1 & NADP-dependent alcohol hydrogenase, putative & $\operatorname{adhA}$ & 0.753 & $1.68 \mathrm{E}-03$ & 39.306 & 6.59 & 24.1 & 8 & 134.39 \\
\hline c62046_g1_orf1 & hypothetical protein DAPPUDRAFT_219795 & Hsp67Bb & 0.765 & $9.70 \mathrm{E}-03$ & 13.655 & 9.05 & 7.9 & 1 & 16.265 \\
\hline c62532_g1 & & Unknown & 0.757 & $4.40 \mathrm{E}-02$ & 40.635 & 5.17 & 7.4 & 2 & 62.044 \\
\hline
\end{tabular}

F1 ratio: the average ratio for three replicates of F1-M versus F1-C. MW: molecular weight. pI: isoelectric point. AASC: amino acid sequence coverage. MP: matched unique peptide. 
Table S7. The up-regulated proteins for Tigriopus japonicus in the recovery generation (F2) after pre-multigenerational exposure to microplastics treatment $(0.23 \mathrm{mg} / \mathrm{L})$ versus ambient condition (i.e., F2-M versus F2-C).

\begin{tabular}{|c|c|c|c|c|c|c|c|c|c|}
\hline Protein accession & Protein description & Gene name & F2 ratio & $P$ value & MW [Da] & pI & AASC $[\%]$ & MP & Score \\
\hline c10258_g1_orf1 & Peritrophin-1 & Unknown & 1.924 & $1.77 \mathrm{E}-04$ & 30.677 & 4.65 & 17.1 & 4 & 25.852 \\
\hline c10406_g1_orf1 & PREDICTED: collagen alpha-1(II) chain-like & COL1A2 & 1.537 & $2.50 \mathrm{E}-03$ & 153.57 & 8.2 & 1.6 & 2 & 16.481 \\
\hline c10423_g1 & & Unknown & 2.608 & $2.02 \mathrm{E}-04$ & 31.35 & 7.88 & 3.7 & 1 & 7.841 \\
\hline c10866_g1 & & Unknown & 1.526 & $1.03 \mathrm{E}-04$ & 43.086 & 9.24 & 17.8 & 7 & 44.06 \\
\hline c1102_g1_orf1 & ACYPI009426 & Unknown & 1.377 & $2.74 \mathrm{E}-03$ & 23.308 & 9.06 & 5 & 1 & 7.2838 \\
\hline c11796_g1 & & Unknown & 1.464 & $1.75 \mathrm{E}-05$ & 102.91 & 9.18 & 7.4 & 9 & 54.751 \\
\hline c12204_g1_orf1 & hypothetical protein DAPPUDRAFT_226094 & Unknown & 1.451 & 4.65E-04 & 26.437 & 4.43 & 3.7 & 1 & 12.211 \\
\hline c12796_g1_orf1 & putative cuticle protein & Unknown & 1.325 & $4.17 \mathrm{E}-02$ & 9.2429 & 4.73 & 10.8 & 1 & 6.8065 \\
\hline c12828_g1_orf1 & hypothetical protein DAPPUDRAFT_309370 & up210 & 2.278 & $6.44 \mathrm{E}-05$ & 103.38 & 4.78 & 4.8 & 5 & 35.801 \\
\hline c12943_g1 & & Unknown & 2.261 & $1.55 \mathrm{E}-04$ & 18.348 & 9.05 & 10.6 & 2 & 22.864 \\
\hline c13035_g1_orf1 & Myosin light chain alkali & Mlc1 & 1.484 & $2.57 \mathrm{E}-04$ & 17.658 & 4.37 & 21.7 & 3 & 45.333 \\
\hline c13228_g1_orf1 & PREDICTED: splicing factor 3A subunit 2-like & SF3A2 & 1.445 & $4.84 \mathrm{E}-02$ & 32.244 & 9.39 & 4.2 & 1 & 6.2307 \\
\hline c13683_g1_orf1 & protein disulfide isomerase, putative & Pdi & 1.783 & 4.21E-05 & 57.725 & 5.01 & 13 & 7 & 76.417 \\
\hline c13812_g1_orf1 & cellulase EGX3 & rsgI6 & 1.325 & $4.48 \mathrm{E}-02$ & 35.687 & 5.07 & 2.9 & 1 & 6.5037 \\
\hline c13852_g1_orf1 & Serine-arginine protein 55 & Srsf4 & 1.304 & $1.24 \mathrm{E}-03$ & 18.123 & 9.47 & 12.5 & 2 & 13.861 \\
\hline c13856_g1_orf1 & hypothetical protein DAPPUDRAFT_47496 & spz3 & 1.952 & $1.39 \mathrm{E}-04$ & 31.159 & 6.13 & 3.7 & 1 & 6.4241 \\
\hline c13896_g1_orf1 & putative SPT transcription factor family member & Unknown & 1.703 & $1.98 \mathrm{E}-03$ & 17.809 & 9.14 & 22.5 & 3 & 19.607 \\
\hline c14023_g1 & & Unknown & 1.384 & $1.16 \mathrm{E}-04$ & 30.655 & 9.42 & 4.9 & 2 & 11.204 \\
\hline c14288_g1_orf1 & $\begin{array}{l}\text { PREDICTED: Down syndrome critical region protein } \\
\text { 3-like }\end{array}$ & DSCR3 & 1.672 & $3.02 \mathrm{E}-04$ & 36.112 & 6.7 & 2.8 & 1 & 5.999 \\
\hline
\end{tabular}


Table S7. To be continued.

\begin{tabular}{|c|c|c|c|c|c|c|c|c|c|}
\hline Protein accession & Protein description & Gene name & F2 ratio & P value & MW [Da] & pI & AASC [\%] & MP & Score \\
\hline c14352_g1 & & Unknown & 1.332 & $8.64 \mathrm{E}-03$ & 57.301 & 5.39 & 10.8 & 5 & 37.274 \\
\hline c14470_g1 & & Unknown & 2.075 & $1.61 \mathrm{E}-04$ & 8.2726 & 10.63 & 12.8 & 1 & 7.0162 \\
\hline c14587_g1_orf1 & beta-N-acetylglucosaminidase & Unknown & 1.316 & $2.99 \mathrm{E}-04$ & 30.227 & 6.67 & 10.8 & 3 & 20.635 \\
\hline c14705_g1_orf1 & PREDICTED: histone-lysine N-methyltransferase SETD7 & setd 7 & 2.211 & $4.40 \mathrm{E}-04$ & 94.649 & 5.85 & 1.7 & 1 & 12.243 \\
\hline c15340_g1_orf1 & hypothetical protein TcasGA2_TC014795 & Unknown & 1.734 & $1.35 \mathrm{E}-04$ & 76.538 & 5.3 & 12.1 & 8 & 64.658 \\
\hline c15469_g1 & & Unknown & 2.373 & $8.42 \mathrm{E}-04$ & 59.032 & 9.66 & 1.7 & 1 & 6.7272 \\
\hline c15695_g1_orf1 & hypothetical protein TcasGA2_TC002960 & MOSPD2 & 1.313 & $2.32 \mathrm{E}-02$ & 62.461 & 6.29 & 4.3 & 2 & 15.996 \\
\hline c15720_g1_orf1 & DnaJ-like protein subfamily $\mathrm{C}$ member 22 & dnajc22 & 1.316 & $1.55 \mathrm{E}-04$ & 41.573 & 9.48 & 3.6 & 1 & 7.1608 \\
\hline c15723_g1_orf1 & PREDICTED: uncharacterized protein LOC102809577 & Unknown & 1.988 & $8.32 \mathrm{E}-05$ & 56.738 & 3.83 & 6.7 & 3 & 41.079 \\
\hline c15772_g1_orf1 & hypothetical protein TcasGA2_TC006730 & ARHGDIB & 1.415 & $1.18 \mathrm{E}-03$ & 24.065 & 4.86 & 9.1 & 1 & 9.8132 \\
\hline c1604_g1_orf1 & hypothetical protein & Unknown & 1.39 & $6.58 \mathrm{E}-03$ & 66.134 & 6.13 & 1.9 & 1 & 6.4321 \\
\hline c16068_g1_orf1 & PREDICTED: sulfhydryl oxidase 2 & QSOX1 & 1.369 & $2.64 \mathrm{E}-03$ & 74.171 & 8.02 & 4.8 & 3 & 48.298 \\
\hline c16194_g1_orf1 & hypothetical protein TcasGA2_TC004625 & $\operatorname{acsbg} 2$ & 1.474 & $5.75 \mathrm{E}-05$ & 74.955 & 6.05 & 11.4 & 8 & 96.729 \\
\hline c16486_g1 & & Unknown & 1.408 & $6.44 \mathrm{E}-03$ & 39.396 & 5.58 & 8.6 & 4 & 34.149 \\
\hline c16561_g1_orf1 & Cerebellin-3 & Unknown & 1.483 & $3.37 \mathrm{E}-04$ & 108.98 & 6.49 & 3.2 & 3 & 20.183 \\
\hline c16564_g1_orf2 & putative SPT transcription factor family member & SPRR3 & 1.722 & $1.08 \mathrm{E}-03$ & 26.179 & 9.72 & 36 & 3 & 17.801 \\
\hline c16615_g2_orf2 & AGAP005507-PA & Syb & 1.336 & $6.46 \mathrm{E}-03$ & 13.04 & 6.49 & 11.3 & 1 & 15.797 \\
\hline c16629_g1_orf2 & cytochrome P450 CYP306A1 & phm & 1.315 & $5.20 \mathrm{E}-03$ & 68.743 & 6.61 & 3.2 & 2 & 16.083 \\
\hline c16657_g1_orf1 & BCS-2 & Unknown & 1.454 & $1.77 \mathrm{E}-02$ & 25.104 & 4.52 & 19.3 & 5 & 31.559 \\
\hline c16691_g1_orf1 & hypothetical protein DAPPUDRAFT_246507 & Unknown & 1.364 & $9.12 \mathrm{E}-03$ & 35.338 & 9.49 & 3.5 & 1 & 6.2481 \\
\hline c16797_g2_orf1 & hypothetical protein DAPPUDRAFT_50816 & Unknown & 1.399 & $1.32 \mathrm{E}-02$ & 52.303 & 5.01 & 2.1 & 1 & 7.5527 \\
\hline
\end{tabular}


Table S7. To be continued.

\begin{tabular}{|c|c|c|c|c|c|c|c|c|c|}
\hline Protein accession & Protein description & Gene name & F2 ratio & $P$ value & MW [Da] & pI & AASC [\%] & MP & Score \\
\hline c16808_g1_orf1 & Stress protein DDR48 & Unknown & 1.399 & 4.13E-05 & 110.22 & 4.78 & 4.2 & 5 & 31.018 \\
\hline c16866_g1_orf1 & crustapain & Cys & 1.321 & $1.97 \mathrm{E}-02$ & 48.611 & 5.17 & 7 & 3 & 19.72 \\
\hline c1691_g1_orf1 & unnamed protein product & KBP & 1.312 & $3.86 \mathrm{E}-03$ & 53.974 & 7.22 & 3.9 & 2 & 14.47 \\
\hline c17069_g1_orf1 & hypothetical protein DAPPUDRAFT_303471 & PDIA4 & 2.156 & $4.00 \mathrm{E}-05$ & 79.401 & 5.16 & 14 & 10 & 72.85 \\
\hline c17265_g1_orf1 & hypothetical protein DAPPUDRAFT_315242 & shakB & 1.354 & $8.03 \mathrm{E}-04$ & 41.916 & 9.34 & 5.9 & 2 & 13.038 \\
\hline c17305_g1 & & PLOD3 & 1.418 & $2.37 \mathrm{E}-04$ & 91.868 & 5.14 & 5.8 & 4 & 28.208 \\
\hline c17353_g1_orf1 & Longitudinals lacking protein-like & lola & 1.598 & $2.90 \mathrm{E}-03$ & 43.273 & 5.51 & 2.3 & 1 & 6.0424 \\
\hline c1739_g1_orf1 & hypothetical protein & Unknown & 1.843 & $2.62 \mathrm{E}-03$ & 63.01 & 4.74 & 1.6 & 1 & 6.5804 \\
\hline c17414_g1_orf1 & PREDICTED: C-terminal-binding protein-like & $\mathrm{CtBP}$ & 1.304 & $9.92 \mathrm{E}-03$ & 42.28 & 7.23 & 10.6 & 4 & 31.804 \\
\hline c17793_g1_orf1 & glucan 1,3-beta-glucosidase & Unknown & 1.414 & $7.75 \mathrm{E}-04$ & 51.043 & 4.46 & 9.2 & 3 & 43.813 \\
\hline c17889_g1_orf2 & AAEL007311-PA & Unknown & 1.769 & $1.14 \mathrm{E}-02$ & 26.424 & 5.83 & 5.1 & 1 & 6.4555 \\
\hline c18131_g1_orf1 & PREDICTED: trithorax group protein osa-like & Unknown & 2.091 & $1.56 \mathrm{E}-03$ & 32.463 & 4.68 & 5.1 & 1 & 135.37 \\
\hline c18349_g1 & & Unknown & 1.421 & $5.83 \mathrm{E}-04$ & 75.031 & 4.18 & 1.5 & 1 & 6.1741 \\
\hline c18437_g1_orf1 & PREDICTED: uromodulin-like & Unknown & 1.362 & $3.88 \mathrm{E}-03$ & 35.283 & 4.39 & 5.4 & 2 & 11.99 \\
\hline c1847_g1 & & Unknown & 1.359 & $5.84 \mathrm{E}-03$ & 102.9 & 5.85 & 0.9 & 1 & 6.5826 \\
\hline c18515_g1_orf1 & putative cuticle protein & Unknown & 1.689 & $6.77 \mathrm{E}-04$ & 12.752 & 4.38 & 11.6 & 1 & 23.954 \\
\hline c18549_g1_orf1 & PREDICTED: beta-lactamase-like protein 2 homolog & CG12375 & 1.386 & $1.88 \mathrm{E}-02$ & 33.258 & 6.74 & 4.7 & 1 & 12.188 \\
\hline c18808_g2_orf1 & predicted protein & HI_1706 & 1.388 & $1.96 \mathrm{E}-03$ & 100.74 & 5.06 & 1.1 & 1 & 6.8229 \\
\hline c18842_g2_orf1 & hypothetical protein & Unknown & 1.339 & $1.78 \mathrm{E}-03$ & 25.876 & 4.77 & 12.1 & 1 & 7.4997 \\
\hline c18907_g1_orf1 & Aminopeptidase $\mathrm{N}$ precursor, putative & Anpep & 1.317 & $1.90 \mathrm{E}-03$ & 107.77 & 4.78 & 5.9 & 5 & 50.57 \\
\hline c19049_g2 & & Unknown & 1.563 & $5.43 \mathrm{E}-04$ & 37.192 & 5.57 & 13.6 & 5 & 107.23 \\
\hline c19080_g1 & & Unknown & 1.623 & $2.20 \mathrm{E}-03$ & 59.979 & 5.75 & 6.9 & 3 & 19.285 \\
\hline
\end{tabular}


Table S7. To be continued.

\begin{tabular}{|c|c|c|c|c|c|c|c|c|c|}
\hline Protein accession & Protein description & Gene name & F2 ratio & P value & MW [Da] & pI & AASC $[\%]$ & MP & Score \\
\hline c19125_g1_orf1 & Trypsin-1 precursor & Unknown & 1.662 & $1.63 \mathrm{E}-04$ & 48.936 & 5.88 & 4.2 & 2 & 13.209 \\
\hline c19125_g2_orf1 & hypothetical protein KGM_11046 & Tmprss $11 \mathrm{~g}$ & 1.822 & $5.16 \mathrm{E}-04$ & 58.721 & 7.88 & 3.7 & 2 & 15.716 \\
\hline c19159_g1 & & Unknown & 1.859 & $1.58 \mathrm{E}-03$ & 25.723 & 6.35 & 15.4 & 3 & 36.986 \\
\hline c19169_g1_orf1 & GM26437 & F40A3.3 & 2.021 & $3.53 \mathrm{E}-05$ & 55.238 & 5.14 & 16.5 & 6 & 145.99 \\
\hline c19222_g1 & & Unknown & 1.85 & $1.44 \mathrm{E}-03$ & 41.414 & 6.28 & 2.6 & 1 & 9.3267 \\
\hline c19280_g2_orf1 & Spzl & $\mathrm{T} 1$ & 1.376 & $1.22 \mathrm{E}-02$ & 30.333 & 6.03 & 7.8 & 2 & 11.682 \\
\hline c19550_g1_orf1 & peritrophin & Unknown & 1.877 & $8.59 \mathrm{E}-04$ & 40.74 & 4.96 & 5.8 & 2 & 16.599 \\
\hline c1975_g1_orf1 & PREDICTED: venom allergen 5-like & Unknown & 1.374 & $1.16 \mathrm{E}-04$ & 42.135 & 6.12 & 9.7 & 3 & 40.658 \\
\hline c19806_g1_orf1 & hypothetical protein L798_02197 & Unknown & 1.426 & $3.44 \mathrm{E}-03$ & 77.165 & 5.88 & 1.4 & 1 & 6.872 \\
\hline c19820_g1_orf1 & $\begin{array}{l}\text { Phosphatidylinositol glycan anchor biosynthesis class } U \\
\text { protein }\end{array}$ & Pigu & 1.349 & $3.64 \mathrm{E}-03$ & 52.279 & 9.36 & 2.4 & 1 & 6.4321 \\
\hline c19854_g1 & & Anpep & 1.368 & $1.70 \mathrm{E}-03$ & 69.554 & 4.49 & 2.8 & 2 & 11.786 \\
\hline c20150_g1_orf1 & AAEL013766-PA & Unknown & 1.862 & $1.82 \mathrm{E}-05$ & 50.117 & 4.72 & 4.8 & 2 & 20.318 \\
\hline c20209_g1_orf1 & PREDICTED: uncharacterized protein C6orf168-like & fax & 1.304 & 9.79E-04 & 45.325 & 5.51 & 15.3 & 8 & 52.409 \\
\hline c20300_g1_orf1 & lysine methyltransferase & setd7 & 1.615 & $2.41 \mathrm{E}-04$ & 95.583 & 6.1 & 1.4 & 1 & 11.18 \\
\hline c20365_g1_orf2 & Myosin-VIIa & $\mathrm{ck}$ & 1.336 & $2.38 \mathrm{E}-03$ & 76.492 & 8.84 & 1.4 & 1 & 6.9534 \\
\hline c20400_g1_orf1 & putative cuticle protein & Unknown & 1.315 & $1.52 \mathrm{E}-03$ & 15.365 & 5.18 & 25.9 & 3 & 36.553 \\
\hline c20506_g1_orf1 & AAEL005749-PA & MAN2B1 & 1.306 & $4.60 \mathrm{E}-04$ & 112.04 & 4.75 & 3.3 & 3 & 23.664 \\
\hline c20847_g1_orf1 & $\begin{array}{l}\text { PREDICTED: chromodomain-helicase-DNA-binding } \\
\text { protein } 7 \text { isoform } \mathrm{X} 4\end{array}$ & CHD7 & 1.339 & $1.55 \mathrm{E}-02$ & 400.3 & 5.54 & 0.4 & 1 & 9.8253 \\
\hline c21204_g1_orf1 & hypothetical protein TcasGA2_TC003706 & tbl1xr1-b & 1.301 & $1.03 \mathrm{E}-02$ & 55.729 & 5.64 & 1.9 & 1 & 10.281 \\
\hline c21239_g3_orf1 & Cuticle protein 6 & Unknown & 1.954 & $3.20 \mathrm{E}-04$ & 22.903 & 5.17 & 9.1 & 2 & 18.849 \\
\hline
\end{tabular}


Table S7. To be continued.

\begin{tabular}{|c|c|c|c|c|c|c|c|c|c|}
\hline Protein accession & Protein description & Gene name & F2 ratio & $P$ value & MW [Da] & pI & AASC $[\%]$ & MP & Score \\
\hline c21387_g1_orf1 & hypothetical protein BRAFLDRAFT_81989 & rsgI6 & 2.151 & $1.71 \mathrm{E}-06$ & 54.516 & 5.25 & 10.9 & 5 & 46.797 \\
\hline c21548_g1_orf1 & SPT transcription factor family member & xynB & 1.732 & $2.03 \mathrm{E}-04$ & 106.22 & 4.61 & 7.3 & 3 & 27.367 \\
\hline c21629_g1 & & Unknown & 1.329 & $6.97 \mathrm{E}-04$ & 83.038 & 5.28 & 2.5 & 2 & 11.775 \\
\hline c21671_g1_orf1 & AGAP003629-PA-like protein & $5 \mathrm{NUC}$ & 1.465 & $6.29 \mathrm{E}-05$ & 62.398 & 4.4 & 3 & 2 & 13.406 \\
\hline c21677_g1 & & Unknown & 1.529 & $9.28 \mathrm{E}-03$ & 50.684 & 4 & 1.8 & 1 & 6.3205 \\
\hline c2180_g1_orf1 & hypothetical protein DAPPUDRAFT_311096 & Aqp9 & 1.303 & $2.18 \mathrm{E}-04$ & 34.649 & 5.92 & 5.4 & 2 & 14.512 \\
\hline c21842_g1_orf1 & hypothetical protein & Unknown & 1.501 & $7.48 \mathrm{E}-03$ & 42.345 & 5.35 & 4.8 & 2 & 10.976 \\
\hline c22151_g2 & & Unknown & 2.979 & $2.31 \mathrm{E}-05$ & 32.748 & 5.69 & 2.3 & 1 & -2 \\
\hline c22340_g1_orf1 & PREDICTED: uncharacterized protein LOC100707181 & Unknown & 1.325 & $7.22 \mathrm{E}-04$ & 152.01 & 4.22 & 2.5 & 3 & 29.896 \\
\hline c22444_g1_orf1 & PREDICTED: NADPH oxidase 5-like isoform X2 & OX5 & 1.307 & $8.92 \mathrm{E}-03$ & 153.33 & 7.06 & 2.2 & 3 & 16.881 \\
\hline c22525_g1_orf1 & PREDICTED: uncharacterized protein LOC100877061 & Unknown & 1.808 & $1.38 \mathrm{E}-03$ & 57.254 & 4.09 & 2.5 & 1 & 9.6497 \\
\hline c22589_g1_orf1 & hypothetical protein DAPPUDRAFT_243454 & Ance & 1.333 & $2.36 \mathrm{E}-03$ & 47.706 & 5.82 & 2.9 & 1 & 10.393 \\
\hline c22620_g1 & & Unknown & 1.635 & $5.05 \mathrm{E}-04$ & 50.59 & 5.1 & 9.2 & 4 & 44.269 \\
\hline c22642_g1_orf1 & PREDICTED: girdin-like isoform X2 & CCDC88A & 2.14 & $6.23 \mathrm{E}-04$ & 191.28 & 5.79 & 0.7 & 1 & 6.9844 \\
\hline c22648_g3_orf1 & hypothetical protein DAPPUDRAFT_311633 & Unknown & 1.34 & $4.15 \mathrm{E}-02$ & 46.827 & 5.07 & 3.5 & 1 & 9.7079 \\
\hline c22788_g1_orf1 & hypothetical protein & Unknown & 2.176 & $6.16 \mathrm{E}-04$ & 52.323 & 4.24 & 7.1 & 3 & 46.636 \\
\hline c22979_g1_orf1 & $\begin{array}{l}\text { PREDICTED: serine/threonine-protein kinase Genghis } \\
\text { Khan isoform X2 }\end{array}$ & Cdc42bpb & 1.321 & $2.66 \mathrm{E}-03$ & 134.92 & 5.91 & 0.8 & 1 & 6.6124 \\
\hline c2300_g1_orf1 & Kex2-like protease & Fur1 & 1.302 & $3.65 \mathrm{E}-04$ & 106.96 & 5.82 & 1.6 & 2 & 11.514 \\
\hline c23058_g3_orf1 & Histone $\mathrm{H} 3 \mathrm{c}$ & Unknown & 1.523 & $1.13 \mathrm{E}-06$ & 15.772 & 11.27 & 17.1 & 4 & 26.76 \\
\hline c23134_g4_orf1 & hypothetical protein SINV_00302 & Unknown & 2.329 & $9.36 \mathrm{E}-04$ & 24.221 & 5.26 & 9.7 & 1 & 6.9665 \\
\hline c23158_g1_orf1 & hypothetical protein T265_09208 & Sorl1 & 1.537 & $3.62 \mathrm{E}-03$ & 131.58 & 4.2 & 1.7 & 2 & 11.377 \\
\hline
\end{tabular}


Table S7. To be continued.

\begin{tabular}{|c|c|c|c|c|c|c|c|c|c|}
\hline Protein accession & Protein description & Gene name & F2 ratio & $P$ value & MW [Da] & pI & AASC $[\%]$ & MP & Score \\
\hline c23323_g5 & & Unknown & 1.41 & $2.90 \mathrm{E}-03$ & 26.621 & 4.74 & 15 & 2 & 62.452 \\
\hline c23389_g1 & & Unknown & 1.563 & $5.58 \mathrm{E}-03$ & 77.863 & 6.89 & 1 & 1 & -2 \\
\hline c23401_g2_orf1 & hypothetical protein KGM_18655 & Unknown & 1.315 & $9.68 \mathrm{E}-03$ & 47.681 & 5.31 & 4.5 & 2 & 23.748 \\
\hline c23534_g1_orf1 & PREDICTED: protein crumbs-like isoform X3 & $\mathrm{crb}$ & 1.331 & 4.74E-02 & 261.36 & 4.27 & 1.4 & 3 & 23.095 \\
\hline c23544_g1 & & $\mathrm{Pkn}$ & 1.363 & $1.94 \mathrm{E}-03$ & 182.24 & 7.97 & 1.5 & 2 & 13.403 \\
\hline c23549_g1_orf1 & Myosin-XV] & MYO15A & 1.543 & $5.01 \mathrm{E}-04$ & 384.01 & 8.45 & 1.3 & 5 & 38.672 \\
\hline c23563_g2_orf1 & putative cuticle protein & resilin & 1.403 & 2.77E-02 & 15.885 & 5.2 & 13.5 & 2 & 12.991 \\
\hline c23596_g1_orf1 & PREDICTED: uncharacterized protein LOC100879487 & EGF1 & 2.378 & 7.37E-04 & 395.93 & 4.68 & 2.4 & 7 & 77.656 \\
\hline c23604_g1_orf1 & hypothetical protein DAPPUDRAFT_309386 & $\mathrm{rg}$ & 1.414 & $3.27 \mathrm{E}-03$ & 144.11 & 5.18 & 1.6 & 2 & 14.582 \\
\hline c23648_g2_orf1 & PREDICTED: uncharacterized protein LOC593916 & TY3B-I & 1.345 & $2.34 \mathrm{E}-03$ & 171.69 & 8.91 & 1.5 & 2 & 11.646 \\
\hline c24179_g1_orf1 & hypothetical protein DAPPUDRAFT_305395 & Utp15 & 1.315 & $4.42 \mathrm{E}-03$ & 64.628 & 8.97 & 2.1 & 1 & 18.154 \\
\hline c24337_g1 & & Unknown & 2.217 & $2.20 \mathrm{E}-03$ & 25.557 & 6.2 & 7.8 & 2 & 13.841 \\
\hline c24412_g1_orf1 & hypothetical protein DAPPUDRAFT_327753 & Unknown & 1.899 & $2.63 \mathrm{E}-04$ & 66.392 & 5 & 1.5 & 1 & 6.6101 \\
\hline c24546_g1 & & Unknown & 1.392 & $6.08 \mathrm{E}-03$ & 56.955 & 5.43 & 4 & 2 & 18.507 \\
\hline c24690_g1_orf1 & histone $\mathrm{h} 2 \mathrm{~B}$ & Unknown & 1.336 & $2.64 \mathrm{E}-04$ & 14.457 & 10.22 & 21.4 & 3 & 43.758 \\
\hline c26615_g1_orf1 & hypothetical protein & Unknown & 1.306 & $4.90 \mathrm{E}-03$ & 39.082 & 4.72 & 3.2 & 1 & 42.216 \\
\hline c2662_g1_orf1 & hypothetical protein & Unknown & 1.503 & $1.96 \mathrm{E}-03$ & 22.122 & 6.26 & 21.2 & 4 & 36.611 \\
\hline c2816_g1_orf1 & $\begin{array}{l}\text { Y3633_MYCTO Uncharacterized protein MT3735 } \\
\text { OS=Mycobacterium tuberculosis (strain CDC } 1551 / \\
\text { Oshkosh) GN=MT3735 }\end{array}$ & Unknown & 1.647 & $3.16 \mathrm{E}-02$ & 41.083 & 5.33 & 3 & 1 & 6.352 \\
\hline c2866_g1 & & Unknown & 2.504 & $1.64 \mathrm{E}-04$ & 26.315 & 4.72 & 3.4 & 1 & 6.2095 \\
\hline c2973_g1_orf1 & Enteropeptidase & CORIN & 1.303 & 4.98E-02 & 126.72 & 4.01 & 1.2 & 1 & 6.0969 \\
\hline
\end{tabular}


Table S7. To be continued.

\begin{tabular}{|c|c|c|c|c|c|c|c|c|c|}
\hline Protein accession & Protein description & Gene name & F2 ratio & $P$ value & MW [Da] & pI & AASC $[\%]$ & MP & Score \\
\hline c3015_g1_orf1 & PREDICTED: high mobility group protein B2-like & Dsp1 & 1.585 & $2.96 \mathrm{E}-04$ & 46.792 & 8.67 & 13.7 & 6 & 36.205 \\
\hline c3102_g1_orf1 & putative SPT transcription factor family member & Unknown & 1.652 & 7.80E-03 & 21.317 & 9.5 & 30.3 & 4 & 37.07 \\
\hline c31463_g1_orf1 & hypothetical protein DAPPUDRAFT_307295 & Coll1a1 & 1.628 & $9.44 \mathrm{E}-03$ & 167.39 & 6.44 & 0.8 & 1 & 16.167 \\
\hline c31664_g1 & & Unknown & 1.487 & $8.54 \mathrm{E}-03$ & 44.277 & 4.76 & 3.7 & 1 & 47.819 \\
\hline c31789_g1_orf1 & chymotrypsin-like proteinase & Unknown & 1.357 & $5.34 \mathrm{E}-03$ & 30.934 & 4.29 & 10.1 & 3 & 22.662 \\
\hline c31826_g1_orf1 & hypothetical protein DAPPUDRAFT_311139 & Unknown & 2.27 & $1.01 \mathrm{E}-02$ & 63.368 & 5.95 & 3 & 2 & 14.38 \\
\hline c31857_g1_orf1 & PREDICTED: UV-stimulated scaffold protein A-like & uvssa & 1.569 & $6.62 \mathrm{E}-03$ & 79.014 & 8.7 & 1.7 & 1 & -2 \\
\hline c31923_g1_orf1 & PREDICTED: homeobox protein unc-4-like & Sult1c1 & 1.381 & $5.59 \mathrm{E}-04$ & 40.219 & 5.87 & 12.3 & 4 & 26.191 \\
\hline c32073_g1_orf1 & PREDICTED: hypothetical protein LOC100740550 & Unknown & 2.393 & $3.75 \mathrm{E}-04$ & 91.157 & 5.99 & 7.4 & 5 & 61.592 \\
\hline c32077_g1 & & Unknown & 3.509 & $4.26 \mathrm{E}-05$ & 29.594 & 5.67 & 4.5 & 1 & 15.038 \\
\hline c3267_g1_orf1 & PREDICTED: contactin-like & Cont & 1.382 & $2.12 \mathrm{E}-03$ & 185.53 & 6.01 & 1.5 & 2 & 14.051 \\
\hline c33690_g1 & & Unknown & 1.461 & $3.61 \mathrm{E}-04$ & 20.081 & 4.85 & 12.2 & 2 & 19.363 \\
\hline c3515_g1_orf1 & hypothetical protein DAPPUDRAFT_233847 & Uro & 1.309 & $1.84 \mathrm{E}-02$ & 35.771 & 9.18 & 15.7 & 5 & 32.846 \\
\hline c3542_g1_orf1 & Chitooligosaccharidolytic beta- $\mathrm{N}$-acetylglucosaminidase & Unknown & 2.411 & $2.64 \mathrm{E}-04$ & 29.271 & 5.36 & 5.9 & 2 & 11.262 \\
\hline c36872_g1 & & Unknown & 1.415 & $6.72 \mathrm{E}-03$ & 15.738 & 5.36 & 12.7 & 2 & 12.574 \\
\hline c39239_g1_orf1 & $\begin{array}{l}\text { Mitochondrial import inner membrane translocase subunit } \\
\text { Tim17-A }\end{array}$ & TIMM17A & 1.719 & $6.52 \mathrm{E}-03$ & 19.305 & 9.1 & 7.7 & 1 & 6.4027 \\
\hline c39241_g1_orf1 & hypothetical protein DAPPUDRAFT_115659 & Unknown & 2.378 & $5.81 \mathrm{E}-04$ & 45.283 & 5.49 & 2.8 & 1 & 6.9658 \\
\hline c39293_g1 & & Unknown & 1.345 & $3.19 \mathrm{E}-04$ & 101.45 & 6.51 & 1.2 & 1 & 33.511 \\
\hline c39521_g1_orf1 & Flexible cuticle protein 12 & Unknown & 2.815 & 4.49E-05 & 16.901 & 5.32 & 9 & 1 & 34.391 \\
\hline c39580_g1_orf1 & PREDICTED: brahma-associated protein of $60 \mathrm{kDa}$ & Bap60 & 1.359 & $3.54 \mathrm{E}-03$ & 60.838 & 9.63 & 5.1 & 3 & 27.625 \\
\hline
\end{tabular}


Table S7. To be continued.

\begin{tabular}{|c|c|c|c|c|c|c|c|c|c|}
\hline Protein accession & Protein description & Gene name & F2 ratio & P value & MW [Da] & pI & AASC $[\%]$ & MP & Score \\
\hline c39619_g1_orf1 & hypothetical protein L798_07481 & Unknown & 2.038 & 7.99E-05 & 65.666 & 5.31 & 3.1 & 2 & 13.829 \\
\hline c39711_g1_orf1 & AGAP011352-PA & FPT1 & 1.362 & $4.55 \mathrm{E}-04$ & 84.549 & 8.23 & 4.5 & 4 & 25.483 \\
\hline c40805_g1_orf1 & PREDICTED: histone H2A.Z-like & Os03g0743400 & 1.43 & $2.04 \mathrm{E}-02$ & 14.164 & 10.44 & 12.7 & 1 & 23.481 \\
\hline c40911_g1_orf1 & RWD domain-containing protein 1 & Rwdd1 & 1.425 & $1.88 \mathrm{E}-03$ & 29.074 & 4.2 & 8 & 2 & 12.671 \\
\hline c40929_g1 & & Unknown & 1.561 & $1.60 \mathrm{E}-03$ & 11.508 & 4.24 & 8.7 & 1 & 10.724 \\
\hline c41036_g1_orf1 & Estrogen sulfotransferase, isoform 2 & SULT1E1 & 1.673 & $2.10 \mathrm{E}-03$ & 40.6 & 5.67 & 8.6 & 3 & 26.568 \\
\hline c4171_g1_orf1 & PREDICTED: glucosamine-6-phosphate isomerase-like & npda1 & 1.309 & $3.68 \mathrm{E}-03$ & 36.73 & 6.95 & 3.7 & 1 & -2 \\
\hline c4196_g1_orf1 & endothelin-converting enzyme, putative & MME & 2.05 & $3.25 \mathrm{E}-04$ & 85.612 & 5.1 & 6.3 & 4 & 37.723 \\
\hline c42284_g1 & & Unknown & 1.357 & $2.00 \mathrm{E}-03$ & 30.253 & 4.98 & 3.7 & 1 & 8.359 \\
\hline c43282_g1_orf1 & 40S ribosomal protein S28 & $\mathrm{RpS} 28 \mathrm{~b}$ & 1.546 & $8.60 \mathrm{E}-04$ & 5.4511 & 9.29 & 38.3 & 1 & 6.7949 \\
\hline c4329_g1_orf1 & hypothetical protein DAPPUDRAFT_301658 & DHCR24 & 1.349 & $2.25 \mathrm{E}-02$ & 58.479 & 7.99 & 4.4 & 2 & 11.802 \\
\hline c46080_g1_orf1 & PREDICTED: maltase-glucoamylase, intestinal-like & Unknown & 1.412 & $1.68 \mathrm{E}-03$ & 8.1662 & 4.65 & 34.7 & 2 & 16.369 \\
\hline c46897_g1_orf1 & hypothetical protein Phum_PHUM331820 & Unknown & 2.159 & $8.82 \mathrm{E}-04$ & 46.886 & 9.21 & 5.2 & 2 & 13.777 \\
\hline c46902_g1_orf1 & putative G-protein coupled receptor & PR158 & 1.694 & $1.68 \mathrm{E}-05$ & 98.083 & 7.12 & 2.4 & 2 & 20.373 \\
\hline c46945_g1_orf1 & Esterase FE4 & Unknown & 2.139 & $1.45 \mathrm{E}-07$ & 76.895 & 5.99 & 2.7 & 2 & 11.86 \\
\hline c46958_g1_orf1 & hypothetical protein & Unknown & 1.594 & 4.14E-03 & 63.783 & 8.49 & 9.6 & 6 & 42.223 \\
\hline c47132_g1_orf1 & Troponin $\mathrm{C}$, isoform 1 & Unknown & 1.304 & $1.90 \mathrm{E}-03$ & 20.107 & 4.01 & 18.8 & 3 & 104.98 \\
\hline c47303_g1 & & Unknown & 1.655 & $2.19 \mathrm{E}-04$ & 26.96 & 5.2 & 30.9 & 5 & 162.35 \\
\hline c47634_g1 & & Unknown & 3.892 & $2.82 \mathrm{E}-04$ & 31.858 & 8.37 & 4.5 & 1 & 10.714 \\
\hline c48548_g1 & & Unknown & 1.587 & 7.02E-03 & 34.688 & 4.5 & 3.5 & 1 & 6.6473 \\
\hline c48715_g1 & & Unknown & 3.268 & $4.12 \mathrm{E}-02$ & 10.062 & 4.78 & 13 & 1 & 15.071 \\
\hline c49240_g1 & & Unknown & 1.43 & $5.64 \mathrm{E}-03$ & 3.8671 & 4.36 & 31.6 & 1 & 8.4739 \\
\hline
\end{tabular}


Table S7. To be continued.

\begin{tabular}{|c|c|c|c|c|c|c|c|c|c|}
\hline Protein accession & Protein description & Gene name & F2 ratio & P value & MW [Da] & pI & AASC $[\%]$ & MP & Score \\
\hline c50163_g1_orf1 & Probable glucosamine 6-phosphate N-acetyltransferase & CG1969 & 1.362 & $9.66 \mathrm{E}-03$ & 22.651 & 9.03 & 5.9 & 1 & 6.8824 \\
\hline c5157_g1 & & Unknown & 1.322 & $1.64 \mathrm{E}-03$ & 78.712 & 5.32 & 5.4 & 4 & 25.489 \\
\hline c54197_g1_orf1 & AGAP011936-PA-like protein & Unknown & 1.805 & $6.41 \mathrm{E}-04$ & 62.779 & 4.93 & 5.4 & 3 & 19.695 \\
\hline c54219_g1_orf1 & hypothetical protein TcasGA2_TC008153 & Unknown & 1.346 & $6.14 \mathrm{E}-03$ & 32.774 & 4.29 & 7 & 2 & 47.334 \\
\hline c54386_g1_orf1 & hypothetical protein DAPPUDRAFT_313646 & $\mathrm{T} 1$ & 1.304 & $1.17 \mathrm{E}-02$ & 47.59 & 6.16 & 1.9 & 1 & 6.2494 \\
\hline c54829_g1 & & Unknown & 1.887 & $3.60 \mathrm{E}-03$ & 18.191 & 4.36 & 7.3 & 1 & 41.419 \\
\hline c55891_g1 & & Unknown & 1.368 & $6.16 \mathrm{E}-03$ & 32.341 & 4.96 & 29.6 & 8 & 111.36 \\
\hline c5680_g1_orf1 & predicted protein & Unknown & 1.654 & 4.46E-05 & 49.507 & 4.93 & 3.4 & 1 & 8.7789 \\
\hline c5764_g1 & & RPS11 & 1.351 & $2.02 \mathrm{E}-05$ & 17.873 & 10.57 & 15.5 & 3 & 17.463 \\
\hline c57692_g1_orf1 & PREDICTED: elongation factor Tu-like & tuf & 1.48 & $7.25 \mathrm{E}-04$ & 7.6295 & 8.3 & 17.1 & 1 & 15.865 \\
\hline c5801_g1_orf2 & PREDICTED: uncharacterized protein LOC101854855 & Unknown & 1.352 & $9.78 \mathrm{E}-03$ & 28.985 & 4.66 & 5 & 1 & 12.322 \\
\hline c61606_g1 & & Unknown & 2.273 & $6.76 \mathrm{E}-04$ & 23.378 & 4.33 & 6.5 & 1 & 30.373 \\
\hline c61681_g1_orf1 & hypothetical protein L798_10158, partial & COL24A1 & 1.794 & $5.97 \mathrm{E}-05$ & 147.29 & 5.31 & 1.7 & 2 & 31.064 \\
\hline c61700_g1_orf1 & $\begin{array}{l}\text { PREDICTED: uncharacterized protein LOC552276 } \\
\text { isoform X1 }\end{array}$ & Unknown & 2.3 & $3.18 \mathrm{E}-04$ & 42.475 & 6.2 & 2.4 & 1 & 6.4661 \\
\hline c61787_g1_orf1 & copper/zinc superoxide dismutase & Sod1 & 1.676 & $5.36 \mathrm{E}-04$ & 25.561 & 6.46 & 12.3 & 3 & 27.853 \\
\hline c61993_g1_orf1 & hypothetical protein DAPPUDRAFT_92990 & Hsp67Bb & 1.51 & $4.88 \mathrm{E}-03$ & 15.562 & 5.6 & 18.8 & 3 & 19.109 \\
\hline c62076_g1 & & Unknown & 1.427 & $1.82 \mathrm{E}-02$ & 45.682 & 5 & 7.3 & 3 & 18.988 \\
\hline c62078_g1_orf1 & $\begin{array}{l}\text { PREDICTED: sodium- and chloride-dependent glycine } \\
\text { transporter 2-like }\end{array}$ & slc6a9 & 1.371 & 4.13E-05 & 74.032 & 4.87 & 1.7 & 1 & 10.436 \\
\hline c62139_g1_orf1 & hypothetical protein DAPPUDRAFT_302366 & CAV1 & 2.959 & $3.54 \mathrm{E}-05$ & 32.117 & 8.97 & 3.5 & 1 & 7.8616 \\
\hline c62205_g1_orf1 & Carboxypeptidase B & CPA1 & 1.53 & $1.26 \mathrm{E}-02$ & 48.982 & 4.52 & 10.6 & 5 & 30.682 \\
\hline
\end{tabular}


Table S7. To be continued.

\begin{tabular}{|c|c|c|c|c|c|c|c|c|c|}
\hline Protein accession & Protein description & Gene name & F2 ratio & P value & MW [Da] & pI & AASC [\%] & MP & Score \\
\hline c62404_g1 & & Unknown & 1.371 & $1.46 \mathrm{E}-02$ & 12.596 & 5.79 & 15.7 & 2 & 11.281 \\
\hline c62644_g1_orf1 & 40S ribosomal protein $\mathrm{S} 14$, putative & rpsK & 1.939 & $5.76 \mathrm{E}-04$ & 7.4825 & 9.59 & 17.1 & 1 & 8.1589 \\
\hline c62830_g1_orf1 & PREDICTED: macrophage mannose receptor 1-like & MRC1 & 1.368 & $2.66 \mathrm{E}-03$ & 33.7 & 4.09 & 3 & 1 & 6.8845 \\
\hline c63254_g1 & & Unknown & 1.541 & $1.67 \mathrm{E}-02$ & 29.6 & 8.26 & 7 & 2 & 12.434 \\
\hline c63422_g1_orf1 & hypothetical protein DAPPUDRAFT_304988 & Unknown & 1.346 & $1.50 \mathrm{E}-02$ & 25.398 & 6.87 & 5.7 & 1 & 8.2667 \\
\hline c6345_g1 & & Unknown & 1.546 & $1.87 \mathrm{E}-05$ & 27.867 & 4.8 & 14.6 & 3 & 68.363 \\
\hline c7557_g1_orf1 & AGAP002366-PA & CG7708 & 1.322 & $3.98 \mathrm{E}-03$ & 74.35 & 5.74 & 2.2 & 1 & 7.8314 \\
\hline c767_g1_orf1 & AAEL008057-PA & MYLK & 1.383 & $4.90 \mathrm{E}-02$ & 40.089 & 5.25 & 2.9 & 1 & 5.9619 \\
\hline c7802_g1_orf1 & Transmembrane emp24 domain-containing protein 10 & bai & 1.374 & $1.53 \mathrm{E}-02$ & 25.11 & 6.27 & 8.7 & 2 & 13.752 \\
\hline c8100_g1_orf1 & SWIB domain-containing protein & spp27 & 1.306 & $1.08 \mathrm{E}-03$ & 16.213 & 9.81 & 20.1 & 3 & 50.982 \\
\hline c8359_g1_orf1 & Beta-parvin & Parva & 1.36 & $2.78 \mathrm{E}-02$ & 43.577 & 5.95 & 9.4 & 3 & 27.647 \\
\hline c8431_g1_orf1 & Structural maintenance of chromosomes protein 4 & smc4 & 1.547 & $7.35 \mathrm{E}-04$ & 153.24 & 5.96 & 1.3 & 2 & 11.579 \\
\hline c8610_g1_orf1 & Flexible cuticle protein 12 & Unknown & 2.801 & 4.49E-05 & 25.11 & 5.1 & 14.6 & 3 & 26.348 \\
\hline c8645_g1 & & Unknown & 2.077 & $1.66 \mathrm{E}-05$ & 6.7026 & 5.29 & 12.1 & 1 & -2 \\
\hline c8758_g1_orf1 & $\begin{array}{l}\text { PREDICTED: uncharacterized protein LOC101899822, } \\
\text { partial }\end{array}$ & Unknown & 1.495 & $5.81 \mathrm{E}-04$ & 61.388 & 4.55 & 8.2 & 4 & 90.677 \\
\hline c9251_g1_orf1 & hypothetical protein DAPPUDRAFT_306142 & HYKK & 1.418 & $2.65 \mathrm{E}-02$ & 45.374 & 5.07 & 5.3 & 2 & 15.277 \\
\hline c9340_g1_orf1 & Carboxypeptidase B & Unknown & 1.343 & $6.81 \mathrm{E}-04$ & 48.176 & 4.92 & 8.4 & 4 & 28.2 \\
\hline c9652_g1_orf1 & PREDICTED: uncharacterized protein LOC103514108 & Unknown & 1.866 & $2.84 \mathrm{E}-04$ & 32.337 & 8.3 & 4.4 & 1 & 7.1167 \\
\hline c9681_g1_orf2 & hypothetical protein DAPPUDRAFT_307138 & Unknown & 1.382 & $1.50 \mathrm{E}-03$ & 93.184 & 5.44 & 2.2 & 2 & 13.092 \\
\hline c9866_g1_orf1 & hypothetical protein D910_04260, partial & LARP6 & 1.318 & $3.82 \mathrm{E}-02$ & 68.857 & 6.41 & 1.1 & 1 & -2 \\
\hline c9875_g1 & & Unknown & 1.727 & $3.52 \mathrm{E}-03$ & 53.388 & 4.61 & 10.4 & 4 & 52.39 \\
\hline
\end{tabular}


F2 ratio: the average ratio for three replicates of F2-M versus F2-C. MW: molecular weight. pI: isoelectric point. AASC: amino acid sequence coverage. MP: matched unique peptide. 
Table S8. The down-regulated proteins for Tigriopus japonicus in the recovery generation (F2) after pre-multigenerational exposure to microplastics treatment $(0.23 \mathrm{mg} / \mathrm{L})$ versus ambient condition (i.e., F2-M versus $\mathrm{F} 2-\mathrm{C})$.

\begin{tabular}{|c|c|c|c|c|c|c|c|c|c|}
\hline Protein accession & Protein description & Gene name & F2 ratio & $P$ value & MW [Da] & pI & AASC [\%] & MP & Score \\
\hline c10752_g1_orf1 & $\begin{array}{l}\text { PREDICTED: histidine triad nucleotide-binding protein } \\
\text { 1-like }\end{array}$ & Hint2 & 0.557 & $5.60 \mathrm{E}-05$ & 21.372 & 8.6 & 5.6 & 1 & 9.283 \\
\hline c11245_g1_orf1 & hypothetical protein DAPPUDRAFT_198965 & Wars2 & 0.681 & $2.28 \mathrm{E}-02$ & 40.173 & 9.03 & 2.8 & 1 & 6.808 \\
\hline c11251_g1_orf1 & hypothetical protein & Mlc2 & 0.683 & $7.10 \mathrm{E}-03$ & 17.171 & 5.15 & 5.8 & 1 & 6.972 \\
\hline c12000_g1_orf1 & UNKNOWN & Znf474 & 0.758 & $3.30 \mathrm{E}-02$ & 21.872 & 9.32 & 10.5 & 2 & 13.26 \\
\hline c12249_g1_orf1 & Guanine nucleotide binding protein, alpha 11 & na11 & 0.766 & $9.04 \mathrm{E}-04$ & 42.467 & 8.35 & 5 & 2 & 16.87 \\
\hline c12529_g1_orf1 & Muscle LIM protein Mlp84B c & Csrp3 & 0.725 & $4.35 \mathrm{E}-04$ & 25.759 & 8.85 & 23.8 & 5 & 84.00 \\
\hline c12810_g1 & & Unknown & 0.715 & $2.10 \mathrm{E}-03$ & 46.878 & 8.48 & 3.1 & 1 & 7.171 \\
\hline c13167_g1_orf1 & 40S ribosomal protein $\mathrm{S} 7 \mathrm{cc}$ & rps7 & 0.741 & $2.74 \mathrm{E}-03$ & 24.629 & 10.14 & 8.3 & 2 & 14.98 \\
\hline c13430_g1_orf1 & 15-hydroxyprostaglandin dehydrogenase [NAD+] & HPGD & 0.672 & $2.36 \mathrm{E}-03$ & 31.374 & 5.68 & 11.9 & 3 & 73.171 \\
\hline c13594_g1_orf1 & hypothetical protein DAPPUDRAFT_306977 & UPB1 & 0.725 & $3.91 \mathrm{E}-02$ & 44.986 & 6.1 & 10.8 & 4 & 31.81 \\
\hline c13745_g1_orf1 & Heat shock protein beta-1 & HSPB1 & 0.708 & 3.97E-04 & 30.149 & 6.02 & 14.1 & 5 & 40.186 \\
\hline c13782_g1 & & Unknown & 0.561 & $1.80 \mathrm{E}-04$ & 19.865 & 10.03 & 10.1 & 1 & 64.992 \\
\hline c13862_g1_orf1 & glyceraldehyde 3-phosphate dehydrogenase & apdh2 & 0.737 & $2.98 \mathrm{E}-03$ & 36.435 & 6.48 & 25.9 & 6 & 104.85 \\
\hline c13873_g1_orf1 & hypothetical protein TcasGA2_TC009430 & Unknown & 0.701 & $6.79 \mathrm{E}-04$ & 27.016 & 6.13 & 54.8 & 6 & 60.009 \\
\hline c13885_g1 & & Unknown & 0.647 & $7.20 \mathrm{E}-04$ & 61.58 & 9.33 & 2.3 & 1 & 10.036 \\
\hline c14260_g1 & & Unknown & 0.407 & $1.67 \mathrm{E}-02$ & 49.832 & 6.17 & 5.2 & 2 & 20.807 \\
\hline c14270_g1_orf1 & alpha-2-macroglobulin, partial & A2ML1 & 0.658 & $2.16 \mathrm{E}-04$ & 201.62 & 4.6 & 12.4 & 22 & 248.91 \\
\hline c14530_g1 & & Unknown & 0.404 & 4.83E-04 & 50.005 & 8.44 & 3.6 & 1 & 7.2812 \\
\hline c14585_g1_orf1 & GI19738 & Zasp52 & 0.554 & 7.01E-04 & 50.123 & 8.82 & 13.2 & 5 & 57.1 \\
\hline
\end{tabular}


Table S8. To be continued.

\begin{tabular}{|c|c|c|c|c|c|c|c|c|c|}
\hline Protein accession & Protein description & Gene name & F2 ratio & P value & MW [kDa] & pI & AASC [\%] & MP & Score \\
\hline c15247_g1 & & Unknown & 0.419 & $1.78 \mathrm{E}-04$ & 16.71 & 5.2 & 6 & 1 & 10.587 \\
\hline c15426_g1 & & Unknown & 0.496 & $6.39 \mathrm{E}-05$ & 55.202 & 9.76 & 8.5 & 4 & 28.162 \\
\hline c15620_g1_orf1 & PREDICTED: hypothetical protein LOC100661788 c & hsp-16.1 & 0.671 & $6.37 \mathrm{E}-04$ & 30.003 & 7.16 & 12.3 & 4 & 30.285 \\
\hline c16080_g1_orf1 & PREDICTED: hexokinase type 2-like & HK1 & 0.704 & $2.42 \mathrm{E}-03$ & 26.69 & 8.93 & 3.4 & 1 & 6.6181 \\
\hline c16443_g1_orf1 & hypothetical protein L798_10809 & DRG1 & 0.708 & $3.32 \mathrm{E}-03$ & 38.197 & 7.78 & 29 & 11 & 76.742 \\
\hline c16448_g1_orf1 & Ras-related protein Rab-10, partial & RAB10 & 0.405 & $1.56 \mathrm{E}-02$ & 23.782 & 6.4 & 5.7 & 1 & 8.6141 \\
\hline c16537_g1_orf1 & Protein LSM14-like protein, partial & Lsm14b & 0.605 & $1.24 \mathrm{E}-03$ & 53.23 & 9.25 & 10.8 & 4 & 144.33 \\
\hline c16592_g2_orf1 & serpin B8, partial & Spn42Dd & 0.677 & 3.88E-03 & 52.08 & 4.96 & 11.8 & 5 & 49.135 \\
\hline c16955_g1_orf1 & uncharacterized protein LOC411317 precursor & DLL4 & 0.695 & $1.50 \mathrm{E}-03$ & 41.258 & 5.88 & 9.7 & 3 & 54.359 \\
\hline c17033_g1_orf1 & hypothetical protein DAPPUDRAFT_52115 & SLC17A5 & 0.745 & $1.11 \mathrm{E}-02$ & 55.43 & 5.76 & 4.1 & 2 & 30.649 \\
\hline c17110_g1 & & Pkg21D & 0.745 & $6.28 \mathrm{E}-03$ & 104.3 & 8.04 & 4.6 & 4 & 28.904 \\
\hline c17242_g1 & & Unknown & 0.403 & 2.61E-04 & 126.32 & 9.05 & 2.6 & 3 & 20.025 \\
\hline c17294_g1_orf1 & PREDICTED: ATPase inhibitor, mitochondrial-like & Atpif1 & 0.607 & $9.62 \mathrm{E}-04$ & 12.439 & 9.99 & 28.7 & 5 & 32.654 \\
\hline c17585_g1_orf1 & putative ATP-dependent RNA helicase me $31 \mathrm{~b}$, partial & me31B & 0.67 & $3.78 \mathrm{E}-04$ & 51.342 & 8.48 & 22.6 & 11 & 148.33 \\
\hline c1778_g1 & & Unknown & 0.74 & $2.44 \mathrm{E}-03$ & 20.616 & 4.32 & 4.4 & 1 & 6.5363 \\
\hline c17845_g1_orf1 & hypothetical protein DAPPUDRAFT_49170 c & Tmprss2 & 0.575 & $2.14 \mathrm{E}-03$ & 51.305 & 9.08 & 11.4 & 4 & 323.31 \\
\hline c17854_g1_orf1 & 5'-AMP-activated protein kinase subunit beta- 2 & PRKAB1 & 0.763 & $1.28 \mathrm{E}-03$ & 42.35 & 8.98 & 3.2 & 1 & 8.1494 \\
\hline c17980_g1 & & Unknown & 0.668 & $5.12 \mathrm{E}-03$ & 270.14 & 9.46 & 5.2 & 12 & 141.18 \\
\hline c18152_g1 & & Unknown & 0.668 & $7.10 \mathrm{E}-03$ & 22.212 & 4.97 & 12.6 & 1 & 82.149 \\
\hline c18201_g1_orf1 & Probable pyridoxine biosynthesis SNZERR & SNZERR & 0.731 & $2.24 \mathrm{E}-03$ & 35.314 & 5.97 & 8 & 3 & 17.746 \\
\hline
\end{tabular}


Table S8. To be continued.

\begin{tabular}{|c|c|c|c|c|c|c|c|c|c|}
\hline Protein accession & Protein description & Gene name & F2 ratio & P value & MW [kDa] & pI & AASC $[\%]$ & MP & Score \\
\hline c18304_g1_orf1 & $\begin{array}{l}\text { LETM1 and EF-hand domain-containing protein } 1 \text {, } \\
\text { mitochondrial, partial }\end{array}$ & LETM1 & 0.737 & $2.50 \mathrm{E}-03$ & 110.81 & 5.49 & 1.7 & 2 & 11.523 \\
\hline c18781_g1_orf1 & AF512518_1 pyrroline-5-carboxylase synthase c & Aldh18a1 & 0.74 & $3.52 \mathrm{E}-05$ & 93.938 & 6.64 & 11.8 & 10 & 83.234 \\
\hline c18974_g1_orf1 & hypothetical protein DAPPUDRAFT_323318 & Ten-a & 0.768 & $2.52 \mathrm{E}-03$ & 37.877 & 5.05 & 18.1 & 6 & 81.156 \\
\hline c18986_g1_orf1 & $\begin{array}{l}\text { PREDICTED: uncharacterized protein } \text { LOC724917 } \\
\text { isoform X2 }\end{array}$ & Unknown & 0.584 & 3.37E-04 & 52.451 & 8.96 & 5.2 & 2 & 18.042 \\
\hline c19172_g1_orf1 & Neural/ectodermal development factor IMP-L2, partial & zig-4 & 0.632 & $6.10 \mathrm{E}-03$ & 32.268 & 6.4 & 7.2 & 2 & 29.201 \\
\hline c19287_g1_orf1 & hypothetical protein cc & Unknown & 0.752 & $3.89 \mathrm{E}-05$ & 50.733 & 7.69 & 17.2 & 11 & 256.04 \\
\hline c19512_g1_orf1 & heat shock protein HSP70-12A, putative & Hspa12a & 0.723 & $3.78 \mathrm{E}-04$ & 125.77 & 8.97 & 1.6 & 2 & 13.028 \\
\hline c1978_g1_orf1 & conserved hypothetical protein & Esyt3 & 0.751 & $3.23 \mathrm{E}-04$ & 56.143 & 5.27 & 17.9 & 9 & 83.216 \\
\hline c19937_g1_orf1 & PREDICTED: epsin-1 & Epn1 & 0.67 & $4.45 \mathrm{E}-05$ & 69.872 & 5.84 & 7.4 & 4 & 34.366 \\
\hline c20340_g1 & & Unknown & 0.591 & $7.40 \mathrm{E}-04$ & 408.55 & 8.72 & 5.3 & 22 & 161.86 \\
\hline c20364_g1_orf1 & Putative amidohydrolase ytcJ & ytcJ & 0.706 & $7.80 \mathrm{E}-03$ & 60.525 & 6.7 & 1.5 & 1 & 6.4771 \\
\hline c20481_g1_orf1 & Stomatin-like protein 2 & STOML2 & 0.726 & $1.47 \mathrm{E}-02$ & 42.561 & 6.39 & 7.2 & 3 & 41.851 \\
\hline c20666_g1 & & Unknown & 0.768 & $3.62 \mathrm{E}-03$ & 53.414 & 5.92 & 2.8 & 1 & 20.584 \\
\hline c20843_g1_orf1 & dumpy, isoform I & Unknown & 0.731 & $3.58 \mathrm{E}-04$ & 84.031 & 6.3 & 8.9 & 5 & 50.847 \\
\hline c21018_g1_orf1 & GG18889 & dlc & 0.757 & $3.20 \mathrm{E}-02$ & 94.869 & 4.77 & 2.6 & 2 & 14.813 \\
\hline c2104_g1_orf1 & SPT transcription factor family member & Unknown & 0.747 & $5.41 \mathrm{E}-04$ & 34.756 & 4.75 & 10.4 & 3 & 21.265 \\
\hline c21164_g1 & & Unknown & 0.662 & $2.96 \mathrm{E}-03$ & 56.919 & 8.9 & 3.1 & 2 & 12.398 \\
\hline c21303_g1_orf1 & Sorbin and SH3 domain-containing protein 1 & Sorbs 1 & 0.682 & $1.40 \mathrm{E}-03$ & 177.4 & 9.35 & 4.6 & 7 & 79.663 \\
\hline c21398_g1_orf1 & Collagenase precursor & Unknown & 0.744 & $1.86 \mathrm{E}-03$ & 32.524 & 5.98 & 12.8 & 3 & 69.623 \\
\hline
\end{tabular}


Table S8. To be continued.

\begin{tabular}{|c|c|c|c|c|c|c|c|c|c|}
\hline Protein accession & Protein description & Gene name & F2 ratio & P value & MW [kDa] & pI & AASC $[\%]$ & MP & Score \\
\hline c21925_g1_orf1 & $\begin{array}{l}\text { PREDICTED: glutaminase } \\
\text { mitochondrial-like isoform X1 }\end{array}$ & ls & 0.589 & $5.36 \mathrm{E}-04$ & 69.646 & 6.35 & 3.2 & 2 & 18.2 \\
\hline c21933_g1_orf1 & AAEL004834-PA & Unknown & 0.597 & $5.83 \mathrm{E}-05$ & 303.84 & 6.35 & 0.5 & 1 & 11.387 \\
\hline c22233_g1_orf1 & Protein jagged-1 & D1 & 0.569 & $5.01 \mathrm{E}-04$ & 43.535 & 4.38 & 2.3 & 1 & 9.3234 \\
\hline c22550_g3_orf1 & PREDICTED: vinculin & Vinc & 0.739 & $3.72 \mathrm{E}-03$ & 119.21 & 8.25 & 3.8 & 4 & 35.081 \\
\hline c22686_g1_orf1 & hypothetical protein DAPPUDRAFT_328542 & cher & 0.7 & $3.46 \mathrm{E}-03$ & 329.19 & 6.19 & 1.8 & 5 & 38.178 \\
\hline c23199_g3_orf1 & Clotting factor $\mathrm{B}$, partial & Unknown & 0.765 & $3.44 \mathrm{E}-03$ & 93.384 & 6.64 & 2.9 & 2 & 22.988 \\
\hline c23237_g1_orf1 & conserved hypothetical protein & LPO & 0.746 & $1.96 \mathrm{E}-04$ & 83.907 & 5.03 & 13.2 & 8 & 130.2 \\
\hline c23251_g2_orf1 & beta-actin & Unknown & 0.487 & 7.81E-04 & 9.5129 & 9.17 & 36.5 & 1 & 12.007 \\
\hline c23251_g3_orf1 & Actin-5C c & Unknown & 0.757 & $5.58 \mathrm{E}-03$ & 17.835 & 5.2 & 42.5 & 3 & 79.129 \\
\hline c23456_g5_orf1 & PREDICTED: UHRF1-binding protein 1-like isoform X2 & Uhrf1bp11 & 0.739 & $4.60 \mathrm{E}-03$ & 155.15 & 6 & 0.6 & 1 & 6.1676 \\
\hline c23556_g1_orf1 & hypothetical protein DAPPUDRAFT_304363 & Ppn & 0.767 & $5.00 \mathrm{E}-03$ & 160.85 & 5.29 & 12.5 & 15 & 244.42 \\
\hline c23736_g6 & & Unknown & 0.72 & $4.00 \mathrm{E}-04$ & 17.817 & 6.48 & 31.9 & 5 & 71.963 \\
\hline c23851_g1_orf1 & ATP synthase subunit $\mathrm{O}$, mitochondrial precursor & ATPsynO & 0.666 & $1.53 \mathrm{E}-05$ & 32.909 & 9.45 & 21.5 & 8 & 126.94 \\
\hline c23872_g1 & & Px & 0.705 & $4.20 \mathrm{E}-04$ & 35.034 & 6.52 & 15 & 5 & 54.061 \\
\hline c24062_g1_orf1 & hypothetical protein PTSG_10087 & $\begin{array}{l}\text { DDB_G02 } \\
71866\end{array}$ & 0.759 & 4.79E-04 & 36.075 & 9 & 8.5 & 3 & 19.185 \\
\hline c24153_g1_orf1 & vasa c & vas & 0.755 & $3.63 \mathrm{E}-04$ & 66.399 & 5.26 & 15.3 & 8 & 96.991 \\
\hline c24316_g1_orf2 & 39S ribosomal protein L1, mitochondrial & Mrpl1 & 0.758 & $4.52 \mathrm{E}-03$ & 45.622 & 9.21 & 7.2 & 3 & 20.283 \\
\hline c24415_g1_orf1 & Proteasome subunit beta type- 3 & psmb3 & 0.508 & $2.45 \mathrm{E}-03$ & 26.282 & 5.14 & 8.4 & 2 & 13.522 \\
\hline c24600_g1_orf1 & AGAP012591-PA-like protein c & Prss55 & 0.717 & $2.92 \mathrm{E}-03$ & 55.104 & 4.98 & 7.9 & 3 & 30.541 \\
\hline
\end{tabular}


Table S8. To be continued.

\begin{tabular}{|c|c|c|c|c|c|c|c|c|c|}
\hline Protein accession & Protein description & Gene name & F2 ratio & P value & MW [kDa] & pI & AASC [\%] & MP & Score \\
\hline c25627_g1_orf1 & hypothetical protein DAPPUDRAFT_333266 & SNH & 0.753 & $2.34 \mathrm{E}-02$ & 46.033 & 6.07 & 5.8 & 2 & 22.095 \\
\hline c25965_g1_orf1 & hypothetical protein DAPPUDRAFT_230292 & cuta & 0.714 & $3.18 \mathrm{E}-03$ & 28.22 & 7.02 & 3.2 & 1 & 6.4609 \\
\hline c2970_g1_orf1 & hypothetical protein CAPTEDRAFT_222872 & UMPS & 0.759 & $2.34 \mathrm{E}-02$ & 53.104 & 6.96 & 6.5 & 3 & 25.489 \\
\hline c31440_g1_orf1 & cathepsin i & Cp1 & 0.744 & $3.18 \mathrm{E}-04$ & 37.949 & 5.89 & 5 & 1 & 143.18 \\
\hline c31508_g1_orf1 & $\begin{array}{l}\text { DEAA_VIBAL Chitin disaccharide deacetylase OS=Vibrio } \\
\text { alginolyticus } G N=\text { deaA }\end{array}$ & deaA & 0.666 & $1.90 \mathrm{E}-03$ & 34.156 & 8.9 & 7.2 & 2 & 21.713 \\
\hline c31521_g1 & & Unknown & 0.755 & $7.92 \mathrm{E}-03$ & 50.151 & 9.43 & 2.2 & 1 & 10.888 \\
\hline c31551_g1 & & PX2 & 0.693 & $3.45 \mathrm{E}-04$ & 33.812 & 5.96 & 15.7 & 4 & 34.713 \\
\hline c31673_g1 & & Unknown & 0.492 & $1.04 \mathrm{E}-03$ & 18.958 & 4.98 & 5.2 & 1 & 7.392 \\
\hline c31786_g1_orf1 & PREDICTED: sequestosome-1-like & Sqstm1 & 0.759 & $1.08 \mathrm{E}-02$ & 39.104 & 5.29 & 9.3 & 3 & 18.489 \\
\hline c31896_g1_orf1 & peptidoglycan recognition protein, partial & Unknown & 0.751 & $3.28 \mathrm{E}-02$ & 36.873 & 8.86 & 4.8 & 2 & 10.649 \\
\hline c31918_g1_orf1 & $\begin{array}{l}\text { PREDICTED: thiosulfate sulfurtransferase/rhodanese-like } \\
\text { domain-containing protein 3-like c }\end{array}$ & $\begin{array}{l}\text { SPAC4H3. } \\
07 \mathrm{c}\end{array}$ & 0.762 & $9.76 \mathrm{E}-04$ & 17.767 & 9.52 & 12.2 & 2 & 24.911 \\
\hline c3212_g1_orf1 & PREDICTED: serine protease nudel-like & ndl & 0.714 & $7.16 \mathrm{E}-04$ & 197.74 & 5.06 & 10.5 & 18 & 148.77 \\
\hline c3220_g1_orf1 & Superoxide dismutase c & Sod & 0.484 & $2.96 \mathrm{E}-04$ & 16.007 & 5.34 & 6.4 & 1 & 9.112 \\
\hline c3222_g1 & & Unknown & 0.536 & $1.29 \mathrm{E}-02$ & 11.535 & 4.5 & 40.5 & 5 & 61.783 \\
\hline c32693_g1_orf1 & PREDICTED: tubulin beta chain-like & TUBB4B & 0.64 & $1.34 \mathrm{E}-03$ & 12.032 & 4.74 & 29.4 & 1 & 65.694 \\
\hline c3370_g1 & & Unknown & 0.585 & $1.46 \mathrm{E}-03$ & 16.922 & 3.78 & 6 & 1 & 6.4661 \\
\hline c39136_g1_orf1 & phosphoenolpyruvate carboxykinase & Pepck & 0.684 & 2.82E-04 & 71.316 & 5.54 & 8.3 & 6 & 40.193 \\
\hline c39143_g1_orf1 & PREDICTED: adenylosuccinate synthetase & I22153 & 0.764 & $6.64 \mathrm{E}-03$ & 55.74 & 6.94 & 11 & 5 & 69.714 \\
\hline c39295_g1_orf1 & PREDICTED: prostaglandin reductase 1-like & Ptgr1 & 0.737 & $4.12 \mathrm{E}-03$ & 37.566 & 6.38 & 2.6 & 1 & 6.8169 \\
\hline
\end{tabular}


Table S8. To be continued.

\begin{tabular}{|c|c|c|c|c|c|c|c|c|c|}
\hline Protein accession & Protein description & Gene name & F2 ratio & $P$ value & MW [kDa] & pI & AASC $[\%]$ & MP & Score \\
\hline c39383_g1_orf1 & Aquaporin AQPAe.a & AQP & 0.758 & $2.54 \mathrm{E}-03$ & 26.567 & 8.17 & 5.1 & 1 & 10.465 \\
\hline c39462_g1_orf1 & Hsp20/alpha-crystallin c & Unknown & 0.682 & $7.83 \mathrm{E}-04$ & 39.961 & 6.28 & 12.8 & 5 & 37.543 \\
\hline c39879_g1 & & Unknown & 0.672 & $6.62 \mathrm{E}-04$ & 41.703 & 9.52 & 9.8 & 3 & 22.418 \\
\hline c40520_g1_orf1 & Heat shock protein homolog & CRYAB & 0.469 & $2.40 \mathrm{E}-03$ & 25.59 & 6.32 & 18 & 3 & 30.458 \\
\hline c4054_g1_orf1 & PREDICTED: THO complex subunit 4-like & Alyref2 & 0.643 & $1.48 \mathrm{E}-03$ & 30.425 & 11.24 & 3.7 & 1 & 6.7969 \\
\hline c40614_g1_orf1 & Programmed cell death protein 5 & Pdcd5 & 0.648 & $2.00 \mathrm{E}-02$ & 18.273 & 8.06 & 23.2 & 3 & 54.348 \\
\hline c40698_g1 & & Unknown & 0.527 & $3.59 \mathrm{E}-04$ & 61.413 & 4.43 & 7.2 & 3 & 50.681 \\
\hline c4111_g1_orf1 & trypsin & Unknown & 0.577 & $3.04 \mathrm{E}-03$ & 31.349 & 4.3 & 4.4 & 1 & 6.236 \\
\hline c44055_g1_orf1 & PREDICTED: 40S ribosomal protein S28-like & RPS28 & 0.617 & $1.56 \mathrm{E}-02$ & 7.6137 & 10.37 & 16.7 & 1 & 6.405 \\
\hline c4645_g1 & & Unknown & 0.686 & $1.42 \mathrm{E}-03$ & 22.426 & 8.22 & 12.4 & 1 & 43.231 \\
\hline c46725_g1_orf1 & PREDICTED: uncharacterized protein LOC100904956 & Unknown & 0.488 & $1.34 \mathrm{E}-03$ & 35.483 & 10.06 & 4.5 & 1 & 35.308 \\
\hline c46756_g1_orf1 & hypothetical protein & Unknown & 0.705 & $5.88 \mathrm{E}-05$ & 24.79 & 6.19 & 19.6 & 5 & 57.765 \\
\hline c46760_g1 & & Unknown & 0.734 & $2.66 \mathrm{E}-03$ & 64.349 & 8.9 & 14.5 & 7 & 165.4 \\
\hline c46795_g1_orf1 & $\begin{array}{l}\text { NADH dehydrogenase (ubiquinone) } 1 \text { alpha subcomplex, } \\
7,14.5 \mathrm{kDa}\end{array}$ & dufa7 & 0.526 & $1.16 \mathrm{E}-04$ & 13.144 & 9.88 & 6.7 & 1 & 6.3288 \\
\hline c46812_g1_orf1 & Protein NipSnap & ipsnap & 0.732 & $1.21 \mathrm{E}-04$ & 32.828 & 9.17 & 16.3 & 5 & 38.155 \\
\hline c46814_g1_orf1 & Innexin inx $2 \mathrm{c}$ & $\operatorname{Inx} 2$ & 0.754 & $1.44 \mathrm{E}-03$ & 49.118 & 6.46 & 2.1 & 1 & 6.6101 \\
\hline c46819_g1_orf1 & hypothetical protein LOTGIDRAFT_238094 & Unknown & 0.594 & $2.48 \mathrm{E}-03$ & 23.485 & 6.15 & 12.2 & 2 & 31.623 \\
\hline c46822_g1_orf1 & peritrophic membrane protein 1 & Unknown & 0.698 & $1.13 \mathrm{E}-02$ & 29.133 & 4.38 & 12.3 & 3 & 28.284 \\
\hline c46835_g1_orf1 & PREDICTED: uncharacterized protein LOC100882869 & jag1a & 0.674 & 4.38E-03 & 43.97 & 4.67 & 11.9 & 6 & 88.502 \\
\hline
\end{tabular}


Table S8. To be continued.

\begin{tabular}{|c|c|c|c|c|c|c|c|c|c|}
\hline Protein accession & Protein description & Gene name & F2 ratio & P value & MW [kDa] & pI & AASC [\%] & MP & Score \\
\hline c46862_g1_orf1 & putative trypsin & Unknown & 0.433 & $6.30 \mathrm{E}-03$ & 28.358 & 4.41 & 4.8 & 1 & 20.986 \\
\hline c46867_g1_orf1 & Sorting nexin-2, partial & Snx2 & 0.738 & $6.72 \mathrm{E}-03$ & 67.566 & 5.15 & 4.7 & 3 & 19.407 \\
\hline c46961_g1_orf1 & PREDICTED: paxillin-like isoform X5 & Tgfb1i1 & 0.644 & $2.47 \mathrm{E}-02$ & 21.227 & 5.75 & 4.3 & 1 & 6.4771 \\
\hline c47059_g1_orf1 & PREDICTED: translin-like & TSN & 0.718 & 5.03E-04 & 29.177 & 5.53 & 22.2 & 5 & 40.379 \\
\hline c47140_g1 & & Unknown & 0.488 & $5.74 \mathrm{E}-05$ & 54.827 & 5.51 & 6.5 & 2 & 12.332 \\
\hline c5004_g1_orf1 & Cathepsin B & CTSB & 0.758 & $5.70 \mathrm{E}-03$ & 38.398 & 6.31 & 11.3 & 3 & 68.726 \\
\hline c5220_g1_orf1 & PREDICTED: restin homolog isoform $\mathrm{X} 2$ & CLIP-190 & 0.584 & $3.08 \mathrm{E}-03$ & 62.459 & $\begin{array}{l}10.1 \\
8\end{array}$ & 11.1 & 6 & 76.718 \\
\hline c54147_g1_orf1 & metalloproteinase & tll1 & 0.702 & $4.79 \mathrm{E}-04$ & 63.565 & 5 & 3.4 & 2 & 13.638 \\
\hline c54186_g1_orf1 & conserved hypothetical protein & ndrg3 & 0.744 & $8.24 \mathrm{E}-03$ & 41.598 & 5.86 & 15.7 & 5 & 66.838 \\
\hline c54253_g1_orf1 & peroxiredoxin 1 & Jafrac1 & 0.693 & $1.66 \mathrm{E}-03$ & 24.487 & 7.12 & 26.4 & 5 & 61.884 \\
\hline c54263_g1_orf1 & Tubulin alpha-1C chain & tuba & 0.756 & $3.70 \mathrm{E}-03$ & 50.563 & 4.89 & 15.6 & 3 & 36.656 \\
\hline c54281_g1_orf1 & $\begin{array}{l}\text { RBP2A_PLAF7 Reticulocyte-binding protein } 2 \text { homolog a } \\
\text { OS=Plasmodium falciparum (isolate 3D7) GN=PF13_0198 }\end{array}$ & Unknown & 0.688 & $3.66 \mathrm{E}-03$ & 110.41 & 9.01 & 19.8 & 9 & 65.798 \\
\hline c54299_g1 & & Unknown & 0.561 & $5.42 \mathrm{E}-04$ & 16.263 & 4.01 & 7.6 & 1 & 6.6473 \\
\hline c5435_g1_orf1 & serpin 3 & SERPINB8 & 0.634 & $1.02 \mathrm{E}-02$ & 52.141 & 6.21 & 12.9 & 6 & 48.82 \\
\hline c54387_g1_orf1 & Peroxiredoxin-5, mitochondrial & PRDX5 & 0.723 & $4.00 \mathrm{E}-03$ & 21.628 & 8.27 & 25.4 & 5 & 35.107 \\
\hline c54458_g1_orf1 & PREDICTED: crystallin J1A-like & Unknown & 0.746 & $9.57 \mathrm{E}-05$ & 38.143 & 6.35 & 10.4 & 4 & 26.285 \\
\hline c54460_g1_orf1 & D-lactate dehydrogenase & $\operatorname{ldhA}$ & 0.711 & $1.75 \mathrm{E}-04$ & 44.114 & 7.61 & 9.4 & 5 & 40.12 \\
\hline c54575_g1_orf1 & $\begin{array}{l}\text { PREDICTED: uncharacterized protein LOC100867187 } \\
\text { isoform } 1\end{array}$ & Unknown & 0.749 & $6.98 \mathrm{E}-03$ & 19.594 & 5.67 & 7.9 & 1 & 23.67 \\
\hline
\end{tabular}


Table S8. To be continued.

\begin{tabular}{|c|c|c|c|c|c|c|c|c|c|}
\hline Protein accession & Protein description & Gene name & F2 ratio & $P$ value & MW [kDa] & pI & AASC $[\%]$ & MP & Score \\
\hline c54660_g1 & & Unknown & 0.581 & $8.06 \mathrm{E}-05$ & 17.392 & 4.93 & 33.8 & 5 & 68.288 \\
\hline c54752_g1_orf1 & myosin heavy chain & Mhc & 0.556 & $1.16 \mathrm{E}-02$ & 13.853 & 5.65 & 42.3 & 2 & 32.431 \\
\hline c54824_g1_orf1 & astacin-like zinc metalloprotease-like protein & Mep1b & 0.722 & $5.21 \mathrm{E}-04$ & 43.596 & 4.77 & 5.6 & 2 & 14.263 \\
\hline c555_g1_orf1 & hypothetical protein DAPPUDRAFT_230557 & CMPK & 0.747 & $1.50 \mathrm{E}-03$ & 38.546 & 9.4 & 5.8 & 2 & 14.793 \\
\hline c55730_g1 & & Unknown & 0.697 & $5.06 \mathrm{E}-03$ & 61.106 & 9.79 & 1.9 & 1 & 7.8522 \\
\hline c5651_g1_orf1 & $\begin{array}{l}\text { PREDICTED: glutaminase kidney isoform, } \\
\text { mitochondrial-like }\end{array}$ & 1s & 0.573 & $3.28 \mathrm{E}-03$ & 80.527 & 7.86 & 2.9 & 4 & 24.575 \\
\hline c5715_g1 & & Unknown & 0.764 & $6.19 \mathrm{E}-04$ & 35.256 & 5.01 & 5.7 & 2 & 12.154 \\
\hline c5730_g1_orf1 & Heat shock protein homolog & Hsp26 & 0.65 & $1.36 \mathrm{E}-03$ & 23.934 & 5.75 & 39 & 8 & 143.69 \\
\hline c5736_g1 & & Unknown & 0.57 & $3.29 \mathrm{E}-02$ & 33.603 & 5.12 & 4 & 1 & 14.965 \\
\hline c5798_g1 & & Unknown & 0.643 & $6.44 \mathrm{E}-04$ & 78.587 & 6.33 & 18 & 12 & 218.63 \\
\hline c5809_g1_orf1 & $\begin{array}{lll}\text { PREDICTED: } & \text { ectonucleoside } & \text { triphosphate } \\
\text { diphosphohydrolase } 1 \text { isoform X1 } & \\
\end{array}$ & ENTPD1 & 0.737 & $5.40 \mathrm{E}-04$ & 74.406 & 6.92 & 3 & 2 & 16.578 \\
\hline c5844_g1_orf1 & hypothetical protein DAPPUDRAFT_307683 & cse11 & 0.768 & $1.12 \mathrm{E}-02$ & 112.67 & 5.51 & 3.2 & 3 & 20.044 \\
\hline c58693_g1_orf1 & triosephosphate isomerase & Tpi & 0.548 & $1.24 \mathrm{E}-03$ & 8.9779 & 4.68 & 12.9 & 1 & 6.8678 \\
\hline c5880_g1 & & Unknown & 0.302 & $7.41 \mathrm{E}-04$ & 12.659 & 5.11 & 21.9 & 2 & 18.209 \\
\hline c61588_g1 & & Unknown & 0.512 & $6.21 \mathrm{E}-05$ & 33.853 & 6.01 & 12.5 & 3 & 46.836 \\
\hline c61602_g1_orf1 & Cytochrome c oxidase subunit 4 isoform 2 , mitochondrial & COX4I1 & 0.287 & $8.34 \mathrm{E}-05$ & 25.217 & 7.72 & 10 & 2 & 92.667 \\
\hline c61630_g1_orf1 & ATP synthase-coupling factor 6 , mitochondrial & $\begin{array}{l}\text { ATPsynCf } \\
6\end{array}$ & 0.678 & 3.19E-04 & 15.916 & 8.88 & 34.9 & 5 & 77.384 \\
\hline
\end{tabular}


Table S8. To be continued.

\begin{tabular}{|c|c|c|c|c|c|c|c|c|c|}
\hline Protein accession & Protein description & Gene name & F2 ratio & P value & MW [kDa] & pI & AASC [\%] & MP & Score \\
\hline c61748_g1_orf1 & C-type lectin & Unknown & 0.687 & $6.42 \mathrm{E}-05$ & 53.45 & 6.09 & 26.1 & 11 & 168.87 \\
\hline c61924_g1_orf1 & PDZ and LIM domain protein 1, partial & PDLIM1 & 0.616 & $4.80 \mathrm{E}-03$ & 21.984 & 5.65 & 29.4 & 6 & 87.722 \\
\hline c61939_g1_orf1 & hypothetical protein DAPPUDRAFT_331010 & Unknown & 0.711 & $2.68 \mathrm{E}-02$ & 22.996 & 9.37 & 10.7 & 2 & 15.091 \\
\hline c62303_g1 & & Unknown & 0.607 & $8.04 \mathrm{E}-04$ & 59.725 & 7.08 & 8.8 & 4 & 54.255 \\
\hline c62445_g1_orf1 & PREDICTED: junctophilin-3-like, partial & Unknown & 0.751 & $2.76 \mathrm{E}-02$ & 36.788 & 10.49 & 3.3 & 1 & 5.9954 \\
\hline c8159_g1_orf1 & Probable adenylate kinase isoenzyme F38B2.4 & AK1 & 0.653 & $8.35 \mathrm{E}-04$ & 23.117 & 6.11 & 34.1 & 9 & 88.863 \\
\hline c8326_g1_orf1 & peroxinectin, putative & Pxt & 0.7 & $1.12 \mathrm{E}-03$ & 111.66 & 6.23 & 1.9 & 2 & 12.628 \\
\hline c8377_g1_orf1 & conserved hypothetical protein & odf3 & 0.638 & $8.60 \mathrm{E}-04$ & 85.426 & 9.27 & 15.4 & 11 & 93.016 \\
\hline c8647_g1_orf1 & PREDICTED: tubulin alpha-3 chain-like & Unknown & 0.422 & $2.76 \mathrm{E}-04$ & 7.1603 & 8.58 & 52.4 & 1 & -2 \\
\hline c8658_g1_orf1 & D-arabinose 1-dehydrogenase & LGALDH & 0.736 & $1.58 \mathrm{E}-03$ & 42.017 & 5.52 & 6.4 & 2 & 25.536 \\
\hline c9774_g1 & & Unknown & 0.643 & $1.20 \mathrm{E}-03$ & 27.04 & 4.82 & 8.2 & 2 & 14.14 \\
\hline
\end{tabular}

F2 ratio: the average ratio for three replicates of F2-M versus F2-C. MW: molecular weight. pI: isoelectric point. AASC: amino acid sequence coverage. MP: matched unique peptide. 
Table S9. Enriched protein pathways for the differentially expressed proteins in the copepod Tigriopus japonicus of F1 after two-generation exposure to microplastics $(0.23 \mathrm{mg} / \mathrm{L})$ treatment.

\begin{tabular}{|c|c|c|c|c|c|c|}
\hline Category & $\begin{array}{l}\text { Accession } \\
\text { number }\end{array}$ & Term description & Count & Related protein & $\begin{array}{l}\text { Fisher's } \\
\text { exact test } \\
P \text { value }\end{array}$ & $-\log 10$ ( $P$ value $)$ \\
\hline \multicolumn{7}{|c|}{ Up-regulated } \\
\hline $\begin{array}{l}\text { Molecular } \\
\text { Function }\end{array}$ & GO:0003735 & $\begin{array}{l}\text { structural constituent of } \\
\text { ribosome }\end{array}$ & 4 & $\begin{array}{l}\text { c44055_g1_orf1 c21384_g1_orf1 c1391_g1_orf1 } \\
\text { c62644_g1_orf1 }\end{array}$ & 0.00063 & 3.2 \\
\hline $\begin{array}{l}\text { Molecular } \\
\text { Function }\end{array}$ & GO:0003924 & GTPase activity & 2 & c57692_g1_orf1 c22608_g1_orf1 & 0.020632 & 1.69 \\
\hline $\begin{array}{l}\text { Biological } \\
\text { Process }\end{array}$ & GO:0006412 & translation & 4 & $\begin{array}{l}\text { c44055_g1_orf1 c21384_g1_orf1 c1391_g1_orf1 } \\
\text { c62644_g1_orf1 }\end{array}$ & 0.000558 & 3.25 \\
\hline $\begin{array}{l}\text { Biological } \\
\text { Process }\end{array}$ & GO:0043043 & $\begin{array}{l}\text { peptide biosynthetic } \\
\text { process }\end{array}$ & 4 & $\begin{array}{l}\text { c44055_g1_orf1 c21384_g1_orf1 c1391_g1_orf1 } \\
\text { c62644_g1_orf1 }\end{array}$ & 0.000584 & 3.23 \\
\hline $\begin{array}{l}\text { Biological } \\
\text { Process }\end{array}$ & GO:0010467 & gene expression & 4 & $\begin{array}{l}\text { c44055_g1_orf1 c21384_g1_orf1 c1391_g1_orf1 } \\
\text { c62644_g1_orf1 }\end{array}$ & 0.001815 & 2.74 \\
\hline $\begin{array}{l}\text { Biological } \\
\text { Process }\end{array}$ & GO:0044267 & $\begin{array}{l}\text { cellular protein } \\
\text { metabolic process }\end{array}$ & 4 & $\begin{array}{l}\text { c44055_g1_orf1 c21384_g1_orf1 c1391_g1_orf1 } \\
\text { c62644_g1_orf1 }\end{array}$ & 0.00514 & 2.29 \\
\hline $\begin{array}{l}\text { Cellular } \\
\text { Component }\end{array}$ & GO:0005840 & ribosome & 4 & $\begin{array}{l}\text { c44055_g1_orf1 c21384_g1_orf1 c1391_g1_orf1 } \\
\text { c62644_g1_orf1 }\end{array}$ & 0.000404 & 3.39 \\
\hline $\begin{array}{l}\text { Cellular } \\
\text { Component }\end{array}$ & GO:1990904 & $\begin{array}{l}\text { ribonucleoprotein } \\
\text { complex }\end{array}$ & 4 & $\begin{array}{l}\text { c44055_g1_orf1 c21384_g1_orf1 c1391_g1_orf1 } \\
\text { c62644_g1_orf1 }\end{array}$ & 0.000637 & 3.2 \\
\hline
\end{tabular}


Table S9. To be continued.

\begin{tabular}{|c|c|c|c|c|c|c|}
\hline Category & $\begin{array}{l}\text { Accession } \\
\text { number }\end{array}$ & Term description & Count & Related protein & $\begin{array}{l}\text { Fisher's } \\
\text { exact test } \\
P \text { value }\end{array}$ & $-\log 10(P$ value $)$ \\
\hline $\begin{array}{l}\text { Cellular } \\
\text { Component }\end{array}$ & GO:0044444 & cytoplasmic part & 4 & $\begin{array}{l}\text { c44055_g1_orf1 c21384_g1_orf1 c1391_g1_orf1 } \\
\text { c62644_g1_orf1 }\end{array}$ & 0.008373 & 2.08 \\
\hline $\begin{array}{l}\text { KEGG } \\
\text { Pathway }\end{array}$ & dme 03010 & ribosome & 3 & c44055_g1_orf1 c21384_g1_orf1 c1391_g1_orf1 & 0.001723 & 2.76 \\
\hline $\begin{array}{l}\text { Protein } \\
\text { Domain }\end{array}$ & IPR016186 & $\begin{array}{l}\text { C-type lectin-like/link } \\
\text { domain }\end{array}$ & 3 & c9831_g1 c20556_g1_orf1 c9875_g1 & 0.000189 & 3.72 \\
\hline $\begin{array}{l}\text { Protein } \\
\text { Domain }\end{array}$ & IPR011043 & $\begin{array}{l}\text { Galactose } \\
\text { oxidase/kelch, } \\
\text { beta-propeller }\end{array}$ & 2 & c16486_g1 c14352_g1 & 0.00059 & 3.23 \\
\hline
\end{tabular}

Only the terms with a $p$ value $<0.05$ were considered to be enriched. 
Table S10. Enriched protein pathways for the differentially expressed proteins in the copepod Tigriopus japonicus of the recovery generation (F2) after pre-multigenerational exposure to microplastics $(0.23 \mathrm{mg} / \mathrm{L})$ treatment.

\begin{tabular}{|c|c|c|c|c|c|c|}
\hline Category & $\begin{array}{l}\text { Accession } \\
\text { number }\end{array}$ & Term description & Count & Related protein & $\begin{array}{l}\text { Fisher's } \\
\text { exact test } \\
P \text { value }\end{array}$ & -Log10 ( $P$ value) \\
\hline \multicolumn{7}{|c|}{ Up-regulated } \\
\hline $\begin{array}{l}\text { Molecular } \\
\text { Function }\end{array}$ & GO:0042302 & $\begin{array}{l}\text { structural constituent of } \\
\text { cuticle }\end{array}$ & 11 & $\begin{array}{l}\text { c9652_g1_orf1 c20400_g1_orf1 c39521_g1_orf1 } \\
\text { c23563_g2_orf1 c2662_g1_orf1 c12796_g1_orf1 } \\
\text { c46897_g1_orf1 c21239_g3_orf1 c32073_g1_orf1 } \\
\text { c8610_g1_orf1 c18515_g1_orf1 }\end{array}$ & $9.42 \mathrm{E}-10$ & 9.03 \\
\hline $\begin{array}{l}\text { Molecular } \\
\text { Function }\end{array}$ & GO:0008061 & chitin binding & 7 & $\begin{array}{l}\text { c54197_g1_orf1 c24412_g1_orf1 c10258_g1_orf1 } \\
\text { c19550_g1_orf1 c20150_g1_orf1 c39619_g1_orf1 } \\
\text { c18131_g1_orf1 }\end{array}$ & $1.01 \mathrm{E}-05$ & 5 \\
\hline $\begin{array}{l}\text { Molecular } \\
\text { Function }\end{array}$ & GO:0046982 & $\begin{array}{l}\text { protein heterodimerization } \\
\text { activity }\end{array}$ & 4 & $\begin{array}{l}\text { c40805_g1_orf1 c24690_g1_orf1 c23058_g3_orf1 } \\
\text { c14470_g1 }\end{array}$ & $9.23 \mathrm{E}-05$ & 4.03 \\
\hline $\begin{array}{l}\text { Molecular } \\
\text { Function }\end{array}$ & GO:0005198 & structural molecule activity & 16 & 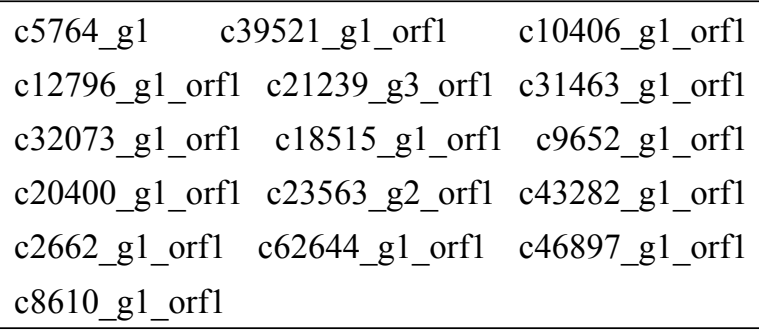 & 0.001012 & 2.99 \\
\hline $\begin{array}{l}\text { Molecular } \\
\text { Function }\end{array}$ & GO:0004553 & $\begin{array}{lr}\text { hydrolase } & \text { activity, } \\
\text { hydrolyzing } & \text { O-glycosyl } \\
\text { compounds } & \end{array}$ & 8 & $\begin{array}{l}\text { c14587_g1_orf1 c61681_g1_orf1 c17793_g1_orf1 } \\
\text { c3542_g1_orf1 c20506_g1_orf1 c13812_g1_orf1 } \\
\text { c63422_g1_orf1 c21387_g1_orf1 }\end{array}$ & 0.003814 & 2.42 \\
\hline
\end{tabular}


Table S10. To be continued.

\begin{tabular}{|c|c|c|c|c|c|c|}
\hline Category & $\begin{array}{l}\text { Accession } \\
\text { number }\end{array}$ & Term description & Count & Related protein & $\begin{array}{l}\text { Fisher's } \\
\text { exact test } \\
P \text { value }\end{array}$ & -Log10 ( $P$ value $)$ \\
\hline $\begin{array}{l}\text { Molecular } \\
\text { Function }\end{array}$ & GO:0008146 & sulfotransferase activity & 3 & c39241_g1_orf1 c31923_g1_orf1 c41036_g1_orf1 & 0.0086 & 0.0487 \\
\hline $\begin{array}{l}\text { Biological } \\
\text { Process }\end{array}$ & GO:0045454 & cell redox homeostasis & 4 & $\begin{array}{l}\text { c23158_g1_orf1 c13683_g1_orf1 c17069_g1_orf1 } \\
\text { c16068_g1_orf1 }\end{array}$ & 0.039752 & 1.4 \\
\hline $\begin{array}{l}\text { Biological } \\
\text { Process }\end{array}$ & GO:1901071 & $\begin{array}{l}\text { glucosamine-containing } \\
\text { compound metabolic process }\end{array}$ & 8 & $\begin{array}{l}\text { c54197_g1_orf1 c24412_g1_orf1 c10258_g1_orf1 } \\
\text { c4171_g1_orf1 c19550_g1_orf1 c20150_g1_orf1 } \\
\text { c39619_g1_orf1 c18131_g1_orf1 }\end{array}$ & $5.84 \mathrm{E}-07$ & 6.23 \\
\hline $\begin{array}{l}\text { Biological } \\
\text { Process }\end{array}$ & GO:0006030 & chitin metabolic process & 7 & $\begin{array}{l}\text { c54197_g1_orf1 c24412_g1_orf1 c10258_g1_orf1 } \\
\text { c19550_g1_orf1 c20150_g1_orf1 c39619_g1_orf1 } \\
\text { c18131_g1_orf1 }\end{array}$ & $4.01 \mathrm{E}-06$ & 5.4 \\
\hline $\begin{array}{l}\text { Biological } \\
\text { Process }\end{array}$ & GO:0005975 & $\begin{array}{l}\text { carbohydrate metabolic } \\
\text { process }\end{array}$ & 13 & $\begin{array}{l}\text { c24412_g1_orf1 c14587_g1_orf1 } \\
\text { c61700_g1_orf1 c4171_g1_orf1 } \\
\text { c61681_g1_orf1 } \\
\text { c54197_g1_orf1 c17793_g1_orf1 c20506_g1_orf1 } \\
\text { c3542_g1_orf1 c13812_g1_orf1 c39619_g1_orf1 } \\
\text { c21387_g1_orf1 }\end{array}$ & 0.002503 & 2.6 \\
\hline $\begin{array}{l}\text { Biological } \\
\text { Process }\end{array}$ & GO:1901135 & $\begin{array}{l}\text { carbohydrate derivative } \\
\text { metabolic process }\end{array}$ & 10 & $\begin{array}{l}\text { c24412_g1_orf1 c10258_g1_orf1 c39711_g1_orf1 } \\
\text { c4171_g1_orf1 c20150_g1_orf1 c54197_g1_orf1 } \\
\text { c19820_g1_orf1 c39619_g1_orf1 c19550_g1_orf1 } \\
\text { c18131_g1_orf1 }\end{array}$ & 0.025497 & 1.59 \\
\hline
\end{tabular}


Table S10. To be continued.

\begin{tabular}{|c|c|c|c|c|c|c|}
\hline Category & $\begin{array}{l}\text { Accession } \\
\text { number }\end{array}$ & Term description & Count & Related protein & $\begin{array}{l}\text { Fisher's } \\
\text { exact test } \\
P \text { value }\end{array}$ & -Log10 ( $P$ value) \\
\hline $\begin{array}{l}\text { Cellular } \\
\text { Component }\end{array}$ & GO:0005694 & chromosome & 5 & $\begin{array}{l}\text { c40805_g1_orf1 c24690_g1_orf1 c23058_g3_orf1 } \\
\text { c14470_g1 c8431_g1_orf1 }\end{array}$ & 0.000133 & 3.88 \\
\hline $\begin{array}{l}\text { Cellular } \\
\text { Component }\end{array}$ & GO:0005576 & extracellular region & 8 & $\begin{array}{l}\text { c1975_g1_orf1 c54197_g1_orf1 c24412_g1_orf1 } \\
\text { c10258_g1_orf1 c19550_g1_orf1 c20150_g1_orf1 } \\
\text { c39619_g1_orf1 c18131_g1_orf1 }\end{array}$ & 0.000211 & 3.68 \\
\hline $\begin{array}{l}\text { Cellular } \\
\text { Component }\end{array}$ & GO:0000785 & chromatin & 4 & $\begin{array}{l}\text { c40805_g1_orf1 c24690_g1_orf1 c23058_g3_orf1 } \\
\text { c14470_g1 }\end{array}$ & 0.00052 & 3.28 \\
\hline $\begin{array}{l}\text { Cellular } \\
\text { Component }\end{array}$ & GO:0032993 & protein-DNA complex & 4 & $\begin{array}{l}\text { c40805_g1_orf1 c24690_g1_orf1 c23058_g3_orf1 } \\
\text { c14470_g1 }\end{array}$ & 0.00052 & 3.28 \\
\hline $\begin{array}{l}\text { KEGG } \\
\text { Pathway }\end{array}$ & dme00520 & $\begin{array}{l}\text { Amino sugar and nucleotide } \\
\text { sugar metabolism }\end{array}$ & 5 & $\begin{array}{l}\text { c3542_g1_orf1 c14587_g1_orf1 c50163_g1_orf1 } \\
\text { c39711_g1_orf1 c4171_g1_orf1 }\end{array}$ & 0.002825 & 2.55 \\
\hline $\begin{array}{l}\text { KEGG } \\
\text { Pathway }\end{array}$ & dme00603 & $\begin{array}{l}\text { Glycosphingolipid } \\
\text { biosynthesis - globo and } \\
\text { isoglobo series }\end{array}$ & 2 & c3542_g1_orf1 c14587_g1_orf1 & 0.009486 & 2.02 \\
\hline $\begin{array}{l}\text { KEGG } \\
\text { Pathway }\end{array}$ & dme00511 & Other glycan degradation & 3 & c20506_g1_orf1 c3542_g1_orf1 c14587_g1_orf1 & 0.010426 & 1.98 \\
\hline $\begin{array}{l}\text { KEGG } \\
\text { Pathway }\end{array}$ & dme00531 & $\begin{array}{l}\text { Glycosaminoglycan } \\
\text { degradation }\end{array}$ & 2 & c3542_g1_orf1 c14587_g1_orf1 & 0.021664 & 1.66 \\
\hline
\end{tabular}


Table S10. To be continued.

\begin{tabular}{|c|c|c|c|c|c|c|}
\hline Category & $\begin{array}{l}\text { Accession } \\
\text { number }\end{array}$ & Term description & Count & Related protein & $\begin{array}{l}\text { Fisher's } \\
\text { exact test } \\
P \text { value }\end{array}$ & -Log10 ( $P$ value) \\
\hline $\begin{array}{l}\text { KEGG } \\
\text { Pathway }\end{array}$ & dme04142 & Lysosome & 4 & $\begin{array}{l}\text { c20506_g1_orf1 c3542_g1_orf1 c14587_g1_orf1 } \\
\text { c16866_g1_orf1 }\end{array}$ & 0.029968 & 1.52 \\
\hline $\begin{array}{l}\text { Protein } \\
\text { Domain }\end{array}$ & IPR002557 & Chitin binding domain & 7 & $\begin{array}{l}\text { c54197_g1_orf1 c24412_g1_orf1 c10258_g1_orf1 } \\
\text { c19550_g1_orf1 c20150_g1_orf1 c39619_g1_orf1 } \\
\text { c18131_g1_orf1 }\end{array}$ & $6.4 \mathrm{E}-06$ & 5.19 \\
\hline $\begin{array}{l}\text { Protein } \\
\text { Domain }\end{array}$ & IPR009072 & Histone-fold & 4 & $\begin{array}{l}\text { c40805_g1_orf1 c24690_g1_orf1 c23058_g3_orf1 } \\
\text { c14470_g1 }\end{array}$ & 7.02E-05 & 4.15 \\
\hline $\begin{array}{l}\text { Protein } \\
\text { Domain }\end{array}$ & IPR032104 & Spaetzle & 3 & c54386_g1_orf1 c19280_g2_orf1 c13856_g1_orf1 & 0.000108 & 3.97 \\
\hline $\begin{array}{l}\text { Protein } \\
\text { Domain }\end{array}$ & IPR011330 & $\begin{array}{l}\text { Glycoside } \\
\text { hydrolase/deacetylase, } \\
\text { beta/alpha-barrel }\end{array}$ & 5 & $\begin{array}{l}\text { c54197_g1_orf1 c24412_g1_orf1 c20506_g1_orf1 } \\
\text { c61700_g1_orf1 c39619_g1_orf1 }\end{array}$ & 0.000221 & 3.66 \\
\hline $\begin{array}{l}\text { Protein } \\
\text { Domain }\end{array}$ & IPR002509 & NodB homology domain & 4 & $\begin{array}{l}\text { c54197_g1_orf1 c24412_g1_orf1 c61700_g1_orf1 } \\
\text { c39619_g1_orf1 }\end{array}$ & 0.000304 & 3.52 \\
\hline $\begin{array}{l}\text { Protein } \\
\text { Domain }\end{array}$ & IPR007125 & Histone $\mathrm{H} 2 \mathrm{~A} / \mathrm{H} 2 \mathrm{~B} / \mathrm{H} 3$ & 3 & c40805_g1_orf1 c24690_g1_orf1 c23058_g3_orf1 & 0.000416 & 3.38 \\
\hline $\begin{array}{l}\text { Protein } \\
\text { Domain }\end{array}$ & IPR029034 & Cystine-knot cytokine & 3 & c54386_g1_orf1 c19280_g2_orf1 c13856_g1_orf1 & 0.000416 & 3.38 \\
\hline
\end{tabular}


Table S10. To be continued.

\begin{tabular}{|c|c|c|c|c|c|c|}
\hline Category & $\begin{array}{l}\text { Accession } \\
\text { number }\end{array}$ & Term description & Count & Related protein & $\begin{array}{l}\text { Fisher's } \\
\text { exact test } \\
P \text { value }\end{array}$ & -Log10 ( $P$ value) \\
\hline $\begin{array}{l}\text { Protein } \\
\text { Domain }\end{array}$ & IPR019835 & SWIB domain & 2 & c8100_g1_orf1 c39580_g1_orf1 & 0.002284 & 2.64 \\
\hline $\begin{array}{l}\text { Protein } \\
\text { Domain }\end{array}$ & IPR000885 & Fibrillar collagen, $\mathrm{C}$-terminal & 2 & c31463_g1_orf1 c10406_g1_orf1 & 0.002284 & 2.64 \\
\hline $\begin{array}{l}\text { Protein } \\
\text { Domain }\end{array}$ & IPR000857 & MyTH4 domain & 2 & c20365_g1_orf2 c23549_g1_orf1 & 0.002284 & 2.64 \\
\hline $\begin{array}{l}\text { Protein } \\
\text { Domain }\end{array}$ & IPR001000 & $\begin{array}{l}\text { Glycoside hydrolase family } 10 \\
\text { domain }\end{array}$ & 2 & c13812_g1_orf1 c21387_g1_orf1 & 0.002284 & 2.64 \\
\hline $\begin{array}{l}\text { Protein } \\
\text { Domain }\end{array}$ & IPR009020 & Proteinase propeptide inhibitor & 3 & c62205_g1_orf1 c2300_g1_orf1 c9340_g1_orf1 & 0.003273 & 2.49 \\
\hline $\begin{array}{l}\text { Protein } \\
\text { Domain }\end{array}$ & IPR001791 & Laminin $\mathrm{G}$ domain & 3 & c23534_g1_orf1 c31463_g1_orf1 c61681_g1_orf1 & 0.005054 & 2.3 \\
\hline $\begin{array}{l}\text { Protein } \\
\text { Domain }\end{array}$ & IPR000863 & Sulfotransferase domain & 2 & c31923_g1_orf1 c41036_g1_orf1 & 0.012857 & 1.89 \\
\hline $\begin{array}{l}\text { Protein } \\
\text { Domain }\end{array}$ & IPR016186 & C-type lectin-like/link domain & 4 & $\begin{array}{lll}\text { c23596_g1_orf1 c3267_g1_orf1 } & \text { c9875_g1 } \\
\text { c62830_g1_orf1 } & \end{array}$ & 0.018837 & 1.72 \\
\hline $\begin{array}{l}\text { Protein } \\
\text { Domain }\end{array}$ & IPR029018 & $\begin{array}{l}\text { Chitobiase/beta-hexosaminidase } \\
\text { domain 2-like }\end{array}$ & 2 & c3542_g1_orf1 c14587_g1_orf1 & 0.02076 & 1.68 \\
\hline $\begin{array}{l}\text { Protein } \\
\text { Domain }\end{array}$ & IPR003146 & $\begin{array}{l}\text { Carboxypeptidase, activation } \\
\text { peptide }\end{array}$ & 2 & c62205_g1_orf1 c9340_g1_orf1 & 0.02076 & 1.68 \\
\hline
\end{tabular}


Table S10. To be continued.

\begin{tabular}{|c|c|c|c|c|c|c|}
\hline Category & $\begin{array}{l}\text { Accession } \\
\text { number }\end{array}$ & Term description & Count & Related protein & \begin{tabular}{|l|} 
Fisher's \\
exact test \\
$P$ value \\
\end{tabular} & $-\log 10$ ( $P$ value $)$ \\
\hline Protein Domain & IPR002018 & Carboxylesterase, type B & 3 & \begin{tabular}{|ll} 
c46945_g1_orf1 & c31826_g1_orf1 \\
c15340_g1_orf1 &
\end{tabular} & 0.021649 & 1.66 \\
\hline Protein Domain & IPR013320 & $\begin{array}{l}\text { Concanavalin A-like } \\
\text { lectin/glucanase domain }\end{array}$ & 4 & $\begin{array}{l}\text { c23596_g1_orf1 c23534_g1_orf1 } \\
\text { c31463_g1_orf1 c61681_g1_orf1 }\end{array}$ & 0.021977 & 1.66 \\
\hline Protein Domain & IPR013766 & Thioredoxin domain & 4 & $\begin{array}{l}\text { c23158_g1_orf1 c13683_g1_orf1 } \\
\text { c17069_g1_orf1 c16068_g1_orf1 }\end{array}$ & 0.021977 & 1.66 \\
\hline Protein Domain & IPR013781 & $\begin{array}{l}\text { Glycoside hydrolase, catalytic } \\
\text { domain }\end{array}$ & 5 & $\begin{array}{l}\text { c17793_g1_orf1 c3542_g1_orf1 c14587_g1_orf1 } \\
\text { c13812_g1_orf1 c21387_g1_orf1 }\end{array}$ & 0.026726 & 1.57 \\
\hline \multicolumn{7}{|l|}{ Down-regulated } \\
\hline $\begin{array}{l}\text { Molecular } \\
\text { Function }\end{array}$ & GO:0016209 & antioxidant activity & 6 & $\begin{array}{l}\text { c8326_g1_orf1 c23237_g1_orf1 c31551_g1 } \\
\text { c3220_g1_orf1 c23872_g1 c54253_g1_orf1 }\end{array}$ & 0.000347 & 3.46 \\
\hline $\begin{array}{l}\text { Molecular } \\
\text { Function }\end{array}$ & GO:0016684 & $\begin{array}{l}\text { oxidoreductase activity, acting } \\
\text { on peroxide as acceptor }\end{array}$ & 5 & $\begin{array}{l}\text { c8326_g1_orf1 c23237_g1_orf1 c31551_g1 } \\
\text { c23872_g1 c54253_g1_orf1 }\end{array}$ & 0.000562 & 3.25 \\
\hline $\begin{array}{l}\text { Molecular } \\
\text { Function }\end{array}$ & GO:0004175 & endopeptidase activity & 11 & \begin{tabular}{|lr} 
c54147_g1_orf1 c17845_g1_orf1 \\
c46862_g1_orf1 c54824_g1_orf1 c4111_g1_orf1 \\
c24415_g1_orf1 24600 g1_orf1 \\
c23199_g3_orf1 c5004_g1_orf1 c21398_g1_orf1 \\
c3212_g1_orf1
\end{tabular} & 0.000561 & 3.25 \\
\hline
\end{tabular}


Table S10. To be continued.

\begin{tabular}{|c|c|c|c|c|c|c|}
\hline Category & $\begin{array}{l}\text { Accession } \\
\text { number }\end{array}$ & Term description & Count & Related protein & $\begin{array}{l}\text { Fisher's } \\
\text { exact test } \\
P \text { value }\end{array}$ & -Log10 ( $P$ value) \\
\hline $\begin{array}{l}\text { Molecular } \\
\text { Function }\end{array}$ & GO:0004252 & $\begin{array}{l}\text { serine-type endopeptidase } \\
\text { activity }\end{array}$ & 7 & $\begin{array}{l}\text { c23199_g3_orf1 c24600_g1_orf1 c17845_g1_orf1 } \\
\text { c46862_g1_orf1 c21398_g1_orf1 c4111_g1_orf1 } \\
\text { c3212_g1_orf1 }\end{array}$ & 0.001963 & 2.71 \\
\hline $\begin{array}{l}\text { Molecular } \\
\text { Function }\end{array}$ & GO:0004602 & glutathione peroxidase activity & 2 & c31551_g1 c23872_g1 & 0.006189 & 2.21 \\
\hline $\begin{array}{l}\text { Molecular } \\
\text { Function }\end{array}$ & GO:0004359 & glutaminase activity & 2 & c5651_g1_orf1 c21925_g1_orf1 & 0.006189 & 2.21 \\
\hline $\begin{array}{l}\text { Biological } \\
\text { Process }\end{array}$ & GO:0006979 & response to oxidative stress & 4 & $\begin{array}{l}\text { c8326_g1_orf1 c23237_g1_orf1 c31551_g1 } \\
\text { c23872_g1 }\end{array}$ & 0.001079 & 2.97 \\
\hline $\begin{array}{l}\text { Biological } \\
\text { Process }\end{array}$ & GO:0050790 & regulation of catalytic activity & 2 & c5004_g1_orf1 c17294_g1_orf1 & 0.001732 & 2.76 \\
\hline $\begin{array}{l}\text { Biological } \\
\text { Process }\end{array}$ & GO:0019856 & $\begin{array}{l}\text { pyrimidine nucleobase } \\
\text { biosynthetic process }\end{array}$ & 2 & c555_g1_orf1 c2970_g1_orf1 & 0.001732 & 2.76 \\
\hline $\begin{array}{l}\text { Biological } \\
\text { Process }\end{array}$ & GO:0009064 & $\begin{array}{l}\text { glutamine family amino acid } \\
\text { metabolic process }\end{array}$ & 3 & c18781_g1_orf1 c5651_g1_orf1 c21925_g1_orf1 & 0.009117 & 2.04 \\
\hline $\begin{array}{l}\text { Biological } \\
\text { Process }\end{array}$ & GO:0090407 & $\begin{array}{l}\text { organophosphate biosynthetic } \\
\text { process }\end{array}$ & 6 & $\begin{array}{l}\text { c18201_g1_orf1 c555_g1_orf1 c39143_g1_orf1 } \\
\text { c61630_g1_orf1 c2970_g1_orf1 c23851_g1_orf1 }\end{array}$ & 0.011876 & 1.93 \\
\hline $\begin{array}{l}\text { Biological } \\
\text { Process }\end{array}$ & GO:0006541 & glutamine metabolic process & 2 & c5651_g1_orf1 c21925_g1_orf1 & 0.015958 & 1.8 \\
\hline $\begin{array}{l}\text { Biological } \\
\text { Process }\end{array}$ & GO:0009165 & $\begin{array}{ll}\text { nucleotide biosynthetic } \\
\text { process }\end{array}$ & 5 & $\begin{array}{l}\text { c555_g1_orf1 c39143_g1_orf1 c61630_g1_orf1 } \\
\text { c2970_g1_orf1 c23851_g1_orf1 }\end{array}$ & 0.019001 & 1.72 \\
\hline
\end{tabular}


Table S10. To be continued.

\begin{tabular}{|c|c|c|c|c|c|c|}
\hline Category & $\begin{array}{l}\text { Accession } \\
\text { number }\end{array}$ & Term description & Count & Related protein & $\begin{array}{l}\text { Fisher's } \\
\text { exact test } \\
P \text { value }\end{array}$ & $-\log 10$ ( $P$ value $)$ \\
\hline $\begin{array}{l}\text { Biological } \\
\text { Process }\end{array}$ & GO:0006508 & proteolysis & 12 & $\begin{array}{l}\text { c31440_g1_orf1 c54147_g1_orf1 c17845_g1_orf1 } \\
\text { c46862_g1_orf1 c54824_g1_orf1 c4111_g1_orf1 } \\
\text { c24415_g1_orf1 c24600_g1_orf1 c23199_g3_orf1 } \\
\text { c5004_g1_orf1 c21398_g1_orf1 c3212_g1_orf1 }\end{array}$ & 0.014977 & 1.82 \\
\hline $\begin{array}{l}\text { Cellular } \\
\text { Component }\end{array}$ & GO:0005874 & microtubule & 3 & c8647_g1_orf1 c54263_g1_orf1 c32693_g1_orf1 & 0.012553 & 1.9 \\
\hline $\begin{array}{l}\text { Cellular } \\
\text { Component }\end{array}$ & GO:0099513 & polymeric cytoskeletal fiber & 3 & c8647_g1_orf1 c54263_g1_orf1 c32693_g1_orf1 & 0.016897 & 1.77 \\
\hline $\begin{array}{l}\text { KEGG } \\
\text { Pathway }\end{array}$ & dme 04213 & $\begin{array}{l}\text { Longevity regulating pathway } \\
\text { - multiple species }\end{array}$ & 7 & $\begin{array}{l}\text { c13745_g1_orf1 c39462_g1_orf1 c17854_g1_orf1 } \\
\text { c5730_g1_orf1 c3220_g1_orf1 c15620_g1_orf1 } \\
\text { c40520_g1_orf1 }\end{array}$ & 0.000135 & 3.87 \\
\hline $\begin{array}{l}\text { KEGG } \\
\text { Pathway }\end{array}$ & dme00471 & $\begin{array}{l}\text { D-Glutamine and D-glutamate } \\
\text { metabolism }\end{array}$ & 2 & c5651_g1_orf1 c21925_g1_orf1 & 0.017876 & 1.75 \\
\hline $\begin{array}{l}\text { KEGG } \\
\text { Pathway }\end{array}$ & dme 00240 & Pyrimidine metabolism & 4 & $\begin{array}{l}\text { c555_g1_orf1 c5809_g1_orf1 c13594_g1_orf1 } \\
\text { c2970_g1_orf1 }\end{array}$ & 0.032519 & 1.49 \\
\hline $\begin{array}{l}\text { KEGG } \\
\text { Pathway }\end{array}$ & dme 04080 & $\begin{array}{l}\text { Neuroactive ligand-receptor } \\
\text { interaction }\end{array}$ & 2 & c46862_g1_orf1 c4111_g1_orf1 & 0.035442 & 1.45 \\
\hline $\begin{array}{l}\text { Protein } \\
\text { Domain }\end{array}$ & IPR008978 & HSP20-like chaperone & 5 & $\begin{array}{l}\text { c13745_g1_orf1 c39462_g1_orf1 c5730_g1_orf1 } \\
\text { c15620_g1_orf1 c40520_g1_orf1 }\end{array}$ & 0.000115 & 3.94 \\
\hline $\begin{array}{l}\text { Protein } \\
\text { Domain }\end{array}$ & IPR008983 & $\begin{array}{l}\text { Tumour necrosis factor-like } \\
\text { domain }\end{array}$ & 3 & c4645_g1 c18152_g1 c61939_g1_orf1 & 0.000884 & 3.05 \\
\hline
\end{tabular}


Table S10. To be continued.

\begin{tabular}{|l|l|l|l|l|l|l|}
\hline Category & $\begin{array}{l}\text { Accession } \\
\text { number }\end{array}$ & Term description & Count & Related protein & $\begin{array}{l}\text { Fisher's } \\
\text { exact test } \\
\boldsymbol{P} \text { value }\end{array}$ & -Log10(P value) \\
\hline $\begin{array}{l}\text { Protein } \\
\text { Domain }\end{array}$ & IPR011060 & $\begin{array}{l}\text { Ribulose-phosphate binding } \\
\text { barrel }\end{array}$ & 2 & c18201_g1_orf1 c2970_g1_orf1 & 0.002094 & 2.68 \\
\hline $\begin{array}{l}\text { Protein } \\
\text { Domain }\end{array}$ & IPR000742 & EGF-like domain & 7 & $\begin{array}{l}\text { c21018_g1_orf1 c46835_g1_orf1 c20843_g1_orf1 } \\
\text { c7335_g1_orf1_c16955_g1_orf1 c18974_g1_orf1 } \\
\text { c22233_g1_orf1 }\end{array}$ & 0.000378 & 3.42 \\
\hline $\begin{array}{l}\text { Protein } \\
\text { Domain }\end{array}$ & IPR001254 & $\begin{array}{l}\text { Serine proteases, trypsin } \\
\text { domain }\end{array}$ & 7 & $\begin{array}{l}\text { c23199_g3_orf1 c24600_g1_orf1 c17845_g1_orf1 } \\
\text { c3212_g1_orf1 }\end{array}$ & 0.000829 & 3.08 \\
\hline $\begin{array}{l}\text { Protein } \\
\text { Domain }\end{array}$ & IPR034035 & $\begin{array}{l}\text { Astacin-like metallopeptidase } \\
\text { domain }\end{array}$ & 2 & c54147_g1_orf1 c54824_g1_orf1 c41398_g1_orf1 c4111_g1_orf1 & 0.006093 & 2.22 \\
\hline $\begin{array}{l}\text { Protein } \\
\text { Domain }\end{array}$ & IPR012338 & $\begin{array}{l}\text { Beta-lactamase/transpeptidase-1 } \\
\text { ike }\end{array}$ & 2 & c5651_g1_orf1 c21925_g1_orf1 & 0.011819 & 1.93 \\
\hline $\begin{array}{l}\text { Protein } \\
\text { Domain }\end{array}$ & IPR023796 & Serpin domain & 2 & c16592_g2_orf1 c5435_g1_orf1 & 0.01911 & 1.72 \\
\hline $\begin{array}{l}\text { Protein } \\
\text { Domain }\end{array}$ & IPR024079 & $\begin{array}{l}\text { Metallopeptidase, catalytic } \\
\text { domain }\end{array}$ & 3 & c54147_g1_orf1 c14260_g1 c54824_g1_orf1 & 0.023739 & 1.62 \\
\hline $\begin{array}{l}\text { Protein } \\
\text { Domain }\end{array}$ & IPR000859 & CUB domain & 3 & c54147_g1_orf1 c17845_g1_orf1 c14270_g1_orf1 & 0.028699 & 1.54 \\
\hline
\end{tabular}

Only the terms with a $p$ value $<0.05$ were considered to be enriched. 